\title{
Corn Silage Management III: Effects of Hybrid, Maturity, and Processing on Nitrogen Metabolism and Ruminal Fermentation
}

\author{
L. M. Johnson, ${ }^{\star}$ J. H. Harrison, ${ }^{*}$ D. Davidson, ${ }^{\star}$ \\ M. Swift†, W. C. Mahannał, and \\ K. Shinners\$ \\ *Department of Animal Sciences, Washington \\ State University, Puyallup, 98371 \\ †Agro Pacific Industries Inc., Chiliwack, B.C., \\ $\ddagger$ Pioneer Hi-Bred International, Des Moines, IA, 50131 \\ $\S$ Department of Biological System Engineering, \\ University of Wisconsin, Madison, 53706
}

\begin{abstract}
Two experiments were conducted to evaluate the effects of maturity and mechanical processing of two hybrids of whole plant corn silage on DM and OM digestibility, nitrogen metabolism, ruminal fermentation, and milk production and composition in lactating Holstein cows. In the first experiment, Pioneer hybrid 3845 whole plant corn was harvested at hard dough, onethird milkline, and two-thirds milkline with a theoretical length-of-cut of $6.4 \mathrm{~mm}$. At each stage of maturity, corn was harvested with (1-mm roll clearance) and without (15.9-mm roll clearance) mechanical processing using a John Deere 5830 harvester with an on-board kernel processor. In the second experiment, Pioneer hybrids 3845 and Quanta were harvested at one-third milkline, two-thirds milkline, and blackline stages of maturity with and without mechanical processing. The theoretical length-of-cut was $12.7 \mathrm{~mm}$. Total tract DM and OM digestibilities were lower for cows fed diets containing processed corn silage in experiment 1 , and tended to be lower for cows fed diets containing unprocessed corn silage in experiment 2. Ruminal acetate concentrations were greater and ruminal propionate concentrations were lower 2 and $6 \mathrm{~h}$ after feeding for cows fed diets containing corn silage harvested at physiological maturity in experiment 2 . This was due to decreased digestion of starch at advanced maturities in experiment 2 . Ruminal $\mathrm{pH}$ tended to decline rapidly after feeding for cows fed hybrid Quanta $(2 \mathrm{~h}$ ) compared to hybrid 3845 ( $5 \mathrm{~h}$ ) corn silage based diets. Ruminal acetate concentrations decreased and ruminal propionate concentrations increased 2 and $6 \mathrm{~h}$ after feeding for cows fed diets containing hybrid Quanta corn silage
\end{abstract}

Received: January 2, 2001.

Accepted April 26, 2002.

Corresponding Author: Dr. Joe Harrison; e-mail: harrison@ puyallup.wsu.edu. compared to hybrid 3845 corn silage. This was related to a greater starch concentration in the corn silage, greater starch intake, and increased rate of starch digestion for cows fed hybrid Quanta corn silage-based diets. Microbial nitrogen flow was lower and feed nitrogen flow was greater for cows fed diets containing hybrid Quanta corn silage. The lower microbial nitrogen flow was due to lower microbial nitrogen concentration and nonammonia nitrogen flow to the duodenum. Milk fat and protein concentrations had a strong quadratic relationship with forage NDF intake as a percentage of body weight. When forage NDF intake as a percentage of body weight dropped below $0.70 \%$, there was a rapid decline in milk fat and protein concentrations.

(Key words: corn silage, mechanical processing, maturity, nitrogen)

Abbreviation key: $\mathbf{B L}=$ blackline, $\mathbf{M L}=$ milkline, $\mathbf{M N F}=$ microbial nitrogen flow, $\mathbf{M U N}=$ milk urea nitrogen, $\mathbf{N A N}$ = nonammonia nitrogen, $\mathbf{N A N M N}$ = nonammonia nonmicrobial nitrogen, $\mathbf{O M}=$ organic matter, TLC $=$ theoretical length-of-cut.

\section{INTRODUCTION}

Whole corn plants are harvested, ensiled, and fed to lactating dairy cattle throughout the United States (Johnson et al., 1999). However, the true nutritive value of corn silage is difficult to determine, as it has both a distinct fibrous (stover) portion and grain portion (kernel). As the corn plant matures, the ratio of stover to grain decreases, and digestibility of the whole plant tends to increase until two-thirds milkline (ML; Johnson et al., 1999). Processing corn plants with an onboard kernel processor alters the physical composition of the corn plant and the nutritive value of the corn silage (Johnson et al., 2002a).

Recently, two studies used current hybrids and feeding strategies to determine the stage of maturity that 
maximizes the nutritive value of corn silage and performance of lactating dairy cows (Harrison et al., 1996; Bal et al., 1997). Milk yield and milk protein production were greatest when corn silage was harvested between one-half ML and two-thirds ML (Harrison et al., 1996; Bal et al., 1997).

Limited research has been conducted to evaluate the effect of processing corn plants with an on-board kernel processor on nutritive value of corn silage and cow performance. In the majority of the animal production studies (Doggett, 1998; Young et al., 1998; Bal et al., 2000a; Weiss and Wyatt, 2000), total tract DM and OM digestibilities were numerically greater for cattle fed diets containing processed corn silage. Only one study (Dhiman et al., 2000) reported no difference in DM digestibility or a decline in OM digestibility. Dry matter digestibility estimates, using macro in situ bags of wet (Harrison et al., 1998) and dry (Bal et al., 2000b) corn silage, have been increased with mechanical processing.

Some studies have reported a significant increase in milk production for cows fed diets containing mechanically processed corn silage compared with unprocessed corn silage (Johnson, 1996; Bal et al., 2000a). Others have reported a numerical increase (Weiss and Wyatt, 2000-conventional hybrid), no difference (Dhiman et al., 2000-2 trials; Weiss and Wyatt, 2000-high oil hybrid), or a significant decrease (Dhiman et al., 2000-1 trial) in milk production for cows fed diets containing processed corn silage. Milk fat concentration (Bal et al., 2000a; Weiss and Wyatt 2000) and yield (Bal et al., 2000a) were also greater for cows fed mechanically processed corn silage based diets. However, milk fat (Dhiman et al., 2000-2 trials) and protein (Dhiman et al., 2000-2 trials; Bal et al., 2000a; Weiss and Wyatt, 2000) concentrations and productions (Dhiman et al., 2000-2 trials; Weiss and Wyatt, 2000) were similar between processed and unprocessed corn silage based diets, and milk protein productions (Dhiman et al., 2000-1 trial) were significantly greater for cows fed unprocessed corn silage based diets.

Limited information has been published about the effects of maturity or mechanical processing of corn silage on ruminal fermentation and $\mathrm{N}$ metabolism. Total tract CP digestibility tended to decrease as the corn plant matured (Johnson and McClure, 1968; Goering et al., 1969; St. Pierre et al., 1987; Bal et al., 1997), and tended to increase (both numerically and significantly) when conventional hybrids of corn silage were mechanically processed (Young et al., 1998; Bal et al., 2000a; Weiss and Wyatt, 2000). Ruminal production of propionate tended to increase and the acetate to propionate ratio decreased when diets containing processed corn silage were fed in some studies (Rojas-Bourrillon et al., 1987; Doggett, 1998; Dhiman et al., 2000). Other studies (Bal et al., 2000a) reported no difference in ruminal propionate production or the acetate to propionate ratio. Some studies have reported no significant difference due to processing corn silage on rumen $\mathrm{pH}$ (Rohr et al., 1986; Doggett, 1998; Jirovec et al., 1998; Bal et al., 2000a), although others have reported a significant decrease at $4 \mathrm{~h}$ after feeding (Rojas-Bourrillon et al., 1987) and averaged across multiple timepoints (Dhiman et al., 2000).

The rapid adoption of on-board kernel processing units has fostered a need for research to define the benefits of mechanically processing corn silage over a wide range of maturities. The objective of these two experiments was to evaluate the effect of maturity and mechanical processing of two corn silage hybrids on DM and $\mathrm{OM}$ digestion, $\mathrm{N}$ metabolism, and ruminal fermentation. The secondary objective was to evaluate milk production and composition in a short-term feeding experiment.

\section{MATERIALS AND METHODS}

\section{Cows, Diets, and Experimental Design}

Two total collection digestion and metabolism studies were conducted using ruminally and duodenally cannulated lactating Holstein cows. Six ruminally and duodenally cannulated lactating Holstein cows were used in a $6 \times 6$ Latin square for experiment 1 . The experimental design structure in experiment 2 was similar to experiment 1 . However, each hybrid (Pioneer hybrids 3845 and Quanta) had a $6 \times 6$ Latin square structure. Six ruminally and duodenally cannulated lactating Holstein cows were used in each Latin square in experiment 2, and the squares were conducted in tandem. In the experiments, corn silage was harvested with a selfpropelled John Deere 5830 harvester (with a kernel processing unit) at a ground speed between 2 and 2.5 $\mathrm{mi} / \mathrm{h}$. The processing equipment was fully active. The harvester consisted of four knives per row, and there were 10 tangential rows. At each stage of maturity, corn silage was harvested with the kernel processing rolls set $1 \mathrm{~mm}$ apart (processed), and with the kernel processing rolls set $15.9 \mathrm{~mm}$ apart (unprocessed). All corn silage was inoculated at the harvester with Pioneer 1132 (Pioneer Hi-Bred Int. Inc., Johnston, IA) inoculant.

All cows used in these experiments were multiparous. Experimental periods were $14 \mathrm{~d}$; the first $10 \mathrm{~d}$ were for adjustment, and the last $4 \mathrm{~d}$ were for collection of samples and data. Cows were individually fed with Calan headgates (American Calan, Inc., Northwood, $\mathrm{NH}$ ) in a free-stall barn during the adaptation periods. Cows were fed sufficient TMR twice daily (1000 and 
Table 1. Ingredients of the diets fed in experiments 1 and 2 (DM Basis).

\begin{tabular}{|c|c|c|}
\hline \multirow[b]{2}{*}{ Ingredient } & \multicolumn{2}{|c|}{ Experiment } \\
\hline & 1 & 2 \\
\hline & $\longrightarrow$ & \\
\hline Corn silage & 26.8 & 26.8 \\
\hline Whole cottonseed & 13.6 & 13.6 \\
\hline Alfalfa hay & 13.2 & 13.2 \\
\hline Barley grain, steam rolled & 12.3 & 14.0 \\
\hline Corn grain, steam rolled & 9.3 & 14.0 \\
\hline Soybean meal $47 \% \mathrm{CP}$, expeller processed & 8.3 & 5.1 \\
\hline Wheat millrun & 6.5 & 4.2 \\
\hline Prolak $^{1}$ & 3.2 & 2.3 \\
\hline Beet pulp & 2.4 & 2.4 \\
\hline Sodium bicarbonate & 1.9 & 1.85 \\
\hline Molasses & 1.0 & 0.84 \\
\hline Limestone & 1.0 & 0.75 \\
\hline TM salt ${ }^{2}$ & 0.26 & \\
\hline Salt & $\ldots$ & 0.35 \\
\hline Biofos $^{3}$ & $\ldots$ & 0.30 \\
\hline Mg oxide & $\ldots$ & 0.19 \\
\hline WSU mineral premix ${ }^{4}$ & & 0.12 \\
\hline $\mathrm{Se}^{5}$ & 0.12 & $\ldots$ \\
\hline Trace mineral $\operatorname{mix}^{6}$ & 0.07 & $\ldots$ \\
\hline Vitamin $\mathrm{D}^{7}$ & 0.02 & $\ldots$ \\
\hline Vitamin $\mathrm{A}^{8}$ & 0.02 & $\ldots$ \\
\hline Vitamin $\mathrm{E}^{9}$ & 0.01 & $\ldots$ \\
\hline
\end{tabular}

${ }^{1}$ Prolak - H.J. Baker \& Bro., Inc., (Stamford, Conneticut).

${ }^{2} \mathrm{TM}$ Salt $-59 \% \mathrm{Cl} ; 38 \% \mathrm{Na} ; 4 \mathrm{ppm} \mathrm{Cu} ; 18$ ppm Fe; 0.7 ppm I; 28 ppm Mn; 35 ppm Zn.

${ }^{3}$ Biofos - IMC, (Lake Forest, Illinois).

${ }^{4}$ WSU Mineral Premix - $5863 \mathrm{kIU} / \mathrm{kg}$ Vitamin A; $2640 \mathrm{kIU} / \mathrm{kg}$ Vitamin D; 14,674 IU/kg Vitamin E; 220 ppm Co; 16,500 ppm Cu; 660 ppm Fe; 880 ppm I; 44,000 ppm Mn; 220 ppm Se; 44,000 ppm $\mathrm{Zn}$.

${ }^{5} \mathrm{Se}-198 \mathrm{ppm}$

${ }^{6} \mathrm{TM}$ Mineral - 20\% Mg; 13,000 ppm Cu; 66,000 ppm Fe; 2,900 ppm I; 44,000 ppm Mn; 120,000 ppm Zn.

${ }^{7}$ Vitamin D - 24,000 kIU/kg.

${ }^{8}$ Vitamin A - 29,964 kIU/kg.

${ }^{9}$ Vitamin E - 498,960 IU/kg.

$1600 \mathrm{~h}$ ) to allow $10 \%$ orts. In all experiments, cows were fed diets formulated to meet NRC specifications (National Research Council, 1989) and containing a similar proportion of corn silage (26.8\% of diet DM), alfalfa hay (13.2\% of diet DM), whole cottonseed (13.6\% of diet DM), and grain mix (46.4\% of diet DM; Table 1).

The effects of hybrid (Pioneer hybrids 3845 and Quanta), maturity (three stages) and mechanical processing (with and without) of corn silage on DM and $\mathrm{OM}$ digestion, $\mathrm{N}$ metabolism, ruminal fermentation, and milk production and composition were evaluated in experiments 1 and 2.

Experiment 1. Cows averaged 126 DIM at the beginning of the experiment. Bovine somatotropin (bST; Posilac, Monsanto Company, St. Louis, MO) was administered to three cows during the study. Hybrid 3845 corn silage was harvested during the 1996 growing season.
Corn silage was harvested at hard dough $(25.3 \% \mathrm{DM})$, one-third ML (28.5\% DM), and two-thirds ML (27.9\% DM-with two light frosts and one killing frost) stages of maturity. The theoretical length-of-cut (TLC) for the corn silage was $6.4 \mathrm{~mm}$.

Experiment 2. All cows were administered bST at 2 -wk intervals during the study. Hybrid 3845 corn silage was harvested during the 1997 growing season at one-third ML (27.1\% DM), two-thirds ML (33.3\% DM), and blackline (BL; 38.2\% DM) stages of maturity. The TLC for the corn silage was $12.7 \mathrm{~mm}$. Cows fed hybrid 3845 corn silage averaged 140 DIM at the beginning of the experiment. Hybrid Quanta corn silage was harvested during the 1997 growing season at one-third ML (34.1\% DM), two-thirds ML (41.5\% DM), and BL (47.5\% DM) stages of maturity. The TLC for the corn silage was $12.7 \mathrm{~mm}$. Cows fed hybrid Quanta corn silage averaged $128 \mathrm{DIM}$ at the beginning of the experiment.

\section{Sample Collection}

Cows were housed in a metabolism barn during the collection period (d 11 to14). Body weights were recorded at the beginning (prior to entering the metabolism barn) and end (prior to entering the free-stall barn) of the collection period. Descriptions of the handling and collection of TMR, feed refusal, corn silage, alfalfa hay, whole cottonseed, grain mix, urine, and feces were discussed in Johnson et al. (2002b). Descriptions of labeling grass silage with $\mathrm{YbCl}_{3} \cdot 6 \mathrm{H}_{2} \mathrm{O}$, dosing $\mathrm{Yb}$ $\mathrm{Cl}_{3} \cdot 6 \mathrm{H}_{2} \mathrm{O}$ labeled grass silage, sampling methods of duodenal and ileal fluid were described in Johnson et al. (2002b).

Samples of ruminal fluid (approximately $300 \mathrm{ml}$ ) were collected 2 and $6 \mathrm{~h}$ after morning feeding, and on d 12 of each collection period using a rubber tube attached to a drill to extract fluid from the rumen. Immediately after collection, $0.5 \mathrm{~g}$ of metaphosphate crystals were added to $125 \mathrm{ml}$ of rumen fluid and frozen at $-20^{\circ} \mathrm{C}$ (Deetz et al., 1989). Ruminal fluid samples were analyzed for ruminal ammonia N, VFA, and lactate. On $\mathrm{d} 11$, the $\mathrm{pH}$ of ruminal fluid was measured $1 \mathrm{~h}$ prior to feeding and every $h$ after feeding for 6 consecutive $h$.

Milk yield was measured twice daily at 0700 and 1900 h. Milk samples were collected two consecutive days during the collection period. The first sample was collected during the p.m. milking on $\mathrm{d} 10$ and the a.m. milking on $d 11$, and two samples were collected during the p.m. milking on $\mathrm{d} 11$ and the a.m. milking of $\mathrm{d} 12$. One milk sample from each $d$ was preserved in 2-bromo2-nitro-propane-1-3-diol and kept refrigerated $\left(6^{\circ} \mathrm{C}\right)$ until analysis on $d 13$. One sample collected on the second $\mathrm{d}$ was frozen at $-20^{\circ} \mathrm{C}$ until analysis. 
Table 2. Dry matter and chemical composition of the diets offered in experiment 1 (Hybrid 3845 harvested in 1996).

\begin{tabular}{|c|c|c|c|c|c|c|}
\hline \multirow[b]{2}{*}{ Item } & \multicolumn{2}{|c|}{ Hard Dough } & \multicolumn{2}{|c|}{ One-third Milkline } & \multicolumn{2}{|c|}{$\begin{array}{l}\text { Two-thirds } \\
\text { Milkline }\end{array}$} \\
\hline & $\operatorname{Proc}^{1}$ & Unproc $^{2}$ & Proc & Unproc & Proc & Unproc \\
\hline $\mathrm{DM}, \%$ & 52.6 & 54.6 & 55.9 & 56.4 & 54.9 & 55.7 \\
\hline Ash, \% of DM & 9.0 & 8.5 & 8.2 & 8.3 & 8.4 & 8.6 \\
\hline $\mathrm{NDF}, \%$ of $\mathrm{DM}$ & 41.4 & 40.3 & 40.6 & 40.4 & 41.3 & 42.0 \\
\hline Forage NDF, $\%$ of DM & 22.7 & 22.0 & 21.3 & 21.8 & 22.1 & 22.2 \\
\hline Forage NDF, \% of Total NDF in TMR & 56.7 & 55.7 & 54.2 & 56.8 & 54.3 & 53.9 \\
\hline $\mathrm{ADF}, \%$ of $\mathrm{DM}$ & 26.5 & 25.3 & 25.5 & 24.8 & 25.6 & 26.1 \\
\hline $\mathrm{CP}, \%$ of $\mathrm{DM}$ & 18.1 & 17.9 & 17.7 & 18.1 & 18.3 & 18.5 \\
\hline $\mathrm{NFC}^{3}, \%$ of $\mathrm{DM}$ & 27.0 & 28.3 & 28.8 & 28.8 & 27.3 & 25.6 \\
\hline Starch, \% of DM & 19.2 & 18.9 & 19.7 & 18.3 & 19.7 & 20.2 \\
\hline Lignin, \% of DM & 5.7 & 5.1 & 5.4 & 5.2 & 4.9 & 4.5 \\
\hline $\mathrm{ADICP}^{4}, \%$ of $\mathrm{DM}$ & 1.7 & 1.2 & 1.3 & 1.6 & 1.4 & 1.4 \\
\hline $\mathrm{NDICP}^{5}, \%$ of DM & 5.1 & 5.1 & 4.6 & 4.8 & 2.0 & 2.1 \\
\hline Crude Fat, $\%$ of DM & 4.5 & 5.0 & 4.6 & 4.5 & 4.7 & 5.3 \\
\hline
\end{tabular}

${ }^{1}$ Proc - Corn silage was harvested with kernel processing rolls set $1 \mathrm{~mm}$ apart.

${ }^{2}$ Unproc - Corn silage was harvested with kernel processing rolls set $15.9 \mathrm{~mm}$ apart.

${ }^{3} \mathrm{NFC}-$ Nonfiber carbohydrates $=100-(\mathrm{CP}+\mathrm{NDF}+$ ash + ether extract $)$.

${ }^{4} \mathrm{ADICP}$ - Acid detergent insoluble CP.

${ }^{5}$ NDICP - Neutral detergent insoluble CP.

\section{Sample Preparation and Analysis}

At the end of each collection period, samples of corn silage, TMR, orts, and feces were dried at $55^{\circ} \mathrm{C}$ in a forced-air oven. Duodenal and ileal samples were thawed and blended at high speed for 3 min with a Warning blender and dried at $55^{\circ} \mathrm{C}$ in a forced-air oven. A separate aliquot containing a wet sample of the homogenized duodenal digesta, ileal digesta, rumen fluid collected 2 and $6 \mathrm{~h}$ after morning feeding, and urine were analyzed for total N (AOAC, 1990). Wet samples of duodenal and ileal fluid and rumen fluid collected 2 and $6 \mathrm{~h}$ after feeding were analyzed for ammonia-N (AOAC, 1990). Ruminal fluid (Erwin et al., 1961) collected 2 and $6 \mathrm{~h}$ after morning feeding were extracted and analyzed for VFA and lactate by gas chromatography (80/20 Carbopack B-DA/4\% Carbowax 20M, Supelco, Inc., Bellefonte, PA).

Dried corn silage, TMR (Tables 2 and 3), orts, duodenal, and fecal samples were ground through a 1-mm screen using a Wiley mill (Arthur H. Thomas, Philadelphia, PA) and analyzed for DM and ash (AOAC, 1990). Corn silage, TMR (Tables 2 and 3), orts, duodenal contents, and feces were analyzed for CP (AOAC, 1990). TMR (Tables 2 and 3) were analyzed for NDF with sulfite (Van Soest et al., 1991), ADF (Goering and Van Soest, 1970), starch (modified starch procedure of Holm et al., 1986 described in Johnson et al., 2002a), ether extract (AOAC, 1990), lignin (Goering and Van Soest, 1970), acid detergent insoluble CP (Goering and Van Soest, 1970), and neutral detergent insoluble CP (Goering and Van Soest, 1970). Nonfiber carbohydrate con- centration for the TMR was calculated using the following formula: nonfiber carbohydrate $=100-(\mathrm{NDF}+\mathrm{CP}$ + ether extract + ash). Dried duodenal and ileal samples were analyzed for purine concentrations (Zinn and Owens, 1986), and $\mathrm{Yb}$ concentration by the inductively coupled plasma procedure (Fassel, 1978) using an extraction procedure described by Williams et al. (1962).

Thawed milk samples were analyzed for fat, protein, and SNF concentration using an infrared analyzer (DHI laboratory, Burlington, WA). Milk samples were analyzed for N (AOAC, 1990) and milk urea-N (MUN; enzymatic in vitro assay for quantitative determination of urea, Roche Diagnostics, 1998).

\section{Statistical Analysis}

The model to test for treatment differences in experiment 1 was;

$$
\mathrm{Y}_{\mathrm{ijk}}=\mu+\mathrm{C}_{\mathrm{i}}+\mathrm{P}_{\mathrm{j}}+\mathrm{T}_{\mathrm{k}}+\mathrm{E}_{\mathrm{ijk}}
$$

Where $\mu$ = overall mean, $\mathrm{C}_{\mathrm{i}}=$ cow effect ( $\mathrm{i}=1$ to 6 ), $\mathrm{P}_{\mathrm{j}}$ $=$ period effect $(\mathrm{j}=1$ to 6$), \mathrm{T}_{\mathrm{k}}=$ treatment effect $(\mathrm{k}=1$ to 6$)$, and $\mathrm{E}_{\mathrm{ijk}}=$ error term.

The model to test for main effects and interaction differences in experiment 1 was;

$$
\mathrm{Y}_{\mathrm{ijkl}}=\mu+\mathrm{C}_{\mathrm{i}}+\mathrm{P}_{\mathrm{j}}+\mathrm{M}_{\mathrm{k}}+\mathrm{K}_{\mathrm{l}}+(\mathrm{M} \times \mathrm{K})_{\mathrm{kl}}+\mathrm{E}_{\mathrm{ijkl}}
$$

Where $\mu$ = overall mean, $\mathrm{C}_{\mathrm{i}}=$ cow effect ( $\mathrm{i}=1$ to 6 ), $\mathrm{P}_{\mathrm{j}}$ $=$ period effect $(\mathrm{j}=1$ to 6$), \mathrm{M}_{\mathrm{k}}=$ maturity effect $(\mathrm{k}=1$ 
Table 3. Dry matter and chemical composition of the diets offered in experiment 2 (Hybrids 3845 and Quanta harvested in 1997).

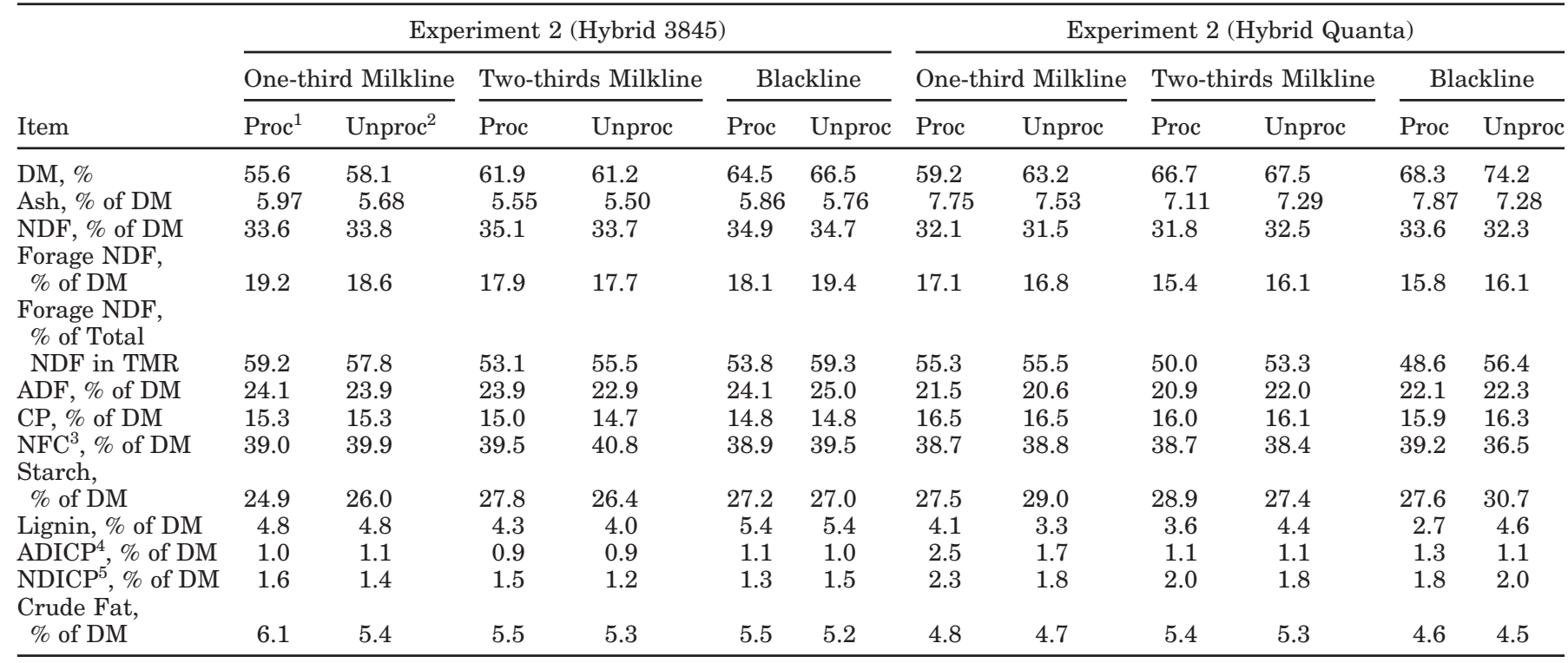

${ }^{1}$ Proc - Corn silage was harvested with kernel processing rolls set $1 \mathrm{~mm}$ apart.

${ }^{2}$ Unproc - Corn silage was harvested with kernel processing rolls set $15.9 \mathrm{~mm}$ apart.

${ }^{3} \mathrm{NFC}-$ Nonfiber carbohydrates $=100-(\mathrm{CP}+\mathrm{NDF}+$ ash + ether extract $)$.

${ }^{4} \mathrm{ADICP}$ - Acid detergent insoluble CP.

${ }^{5}$ NDICP - Neutral detergent insoluble CP.

to 3$), \mathrm{K}_{\mathrm{l}}=$ kernel processing effect $(\mathrm{l}=1$ to 2$),(\mathrm{M} \times \mathrm{K})_{\mathrm{kl}}$ = interaction effect of $\mathrm{M}_{\mathrm{k}}$ and $\mathrm{K}_{\mathrm{l}}$, and $\mathrm{E}_{\mathrm{ijkl}}=$ error term.

The model for analyzing repeated measures in experiment 1 was;

$$
\begin{gathered}
\mathrm{Y}_{\mathrm{ijklm}}=\mu+\mathrm{C}_{\mathrm{i}}+\mathrm{P}_{\mathrm{j}}+\mathrm{M}_{\mathrm{k}}+\mathrm{K}_{\mathrm{l}}+(\mathrm{M} \times \mathrm{K})_{\mathrm{kl}}+(\mathrm{C} \times \mathrm{P} \times \mathrm{M} \\
\times \mathrm{K})_{\mathrm{ijkl}}+\mathrm{T}_{\mathrm{m}}+(\mathrm{M} \times \mathrm{T})_{\mathrm{km}}+(\mathrm{K} \times \mathrm{T})_{\mathrm{lm}}+(\mathrm{M} \times \mathrm{K} \times \mathrm{T})_{\mathrm{klm}} \\
+\mathrm{E}_{\mathrm{ijklm}}
\end{gathered}
$$

Where $\mu$ overall mean, $\mathrm{C}_{\mathrm{i}}=$ cow effect ( $\mathrm{i}=1$ to 6 ), $\mathrm{P}_{\mathrm{j}}$ $=$ period effect $(\mathrm{j}=1$ to 6$), \mathrm{M}_{\mathrm{k}}=$ maturity effect $(\mathrm{k}=1$ to 3$), \mathrm{K}_{\mathrm{l}}=$ kernel processing effect $(\mathrm{l}=1$ to 2$),(\mathrm{M} \times \mathrm{K})_{\mathrm{kl}}$ interaction effect of $\mathrm{M}_{\mathrm{k}}$ and $\mathrm{K}_{\mathrm{l}},(\mathrm{C} \times \mathrm{P} \times \mathrm{M} \times \mathrm{K})_{\mathrm{ijkl}}$ error term for all whole-plot sources of variation, $\mathrm{T}_{\mathrm{m}}=$ time post feeding $(\mathrm{m}=1$ to 7$),(\mathrm{M} \times \mathrm{T})_{\mathrm{km}}=$ interaction effect of $\mathrm{M}_{\mathrm{k}}$ and $\mathrm{T}_{\mathrm{m}},(\mathrm{K} \times \mathrm{T})_{\mathrm{lm}}=$ interaction effect of $\mathrm{K}_{\mathrm{l}}$ and $\mathrm{T}_{\mathrm{m}},(\mathrm{M} \times \mathrm{K} \times \mathrm{T})_{\mathrm{klm}}=$ interaction of $\mathrm{M}_{\mathrm{k}}, \mathrm{K}_{\mathrm{l}}$, and $\mathrm{T}_{\mathrm{m}}$, and $\mathrm{E}_{\mathrm{ijklm}}=$ error term for sub-plot (time) sources of variation.

The model to test for treatment differences in experiment 2 was;

$$
\mathrm{Y}_{\mathrm{ijk}}=\mu+\mathrm{C}_{\mathrm{i}}+\mathrm{P}_{\mathrm{j}}+\mathrm{T}_{\mathrm{k}}+\mathrm{E}_{\mathrm{ijk}}
$$

Where $\mu$ = overall mean, $\mathrm{C}_{\mathrm{i}}=$ cow effect ( $\mathrm{i}=1$ to 6$), \mathrm{P}_{\mathrm{j}}$ $=$ period effect $(\mathrm{j}=1$ to 6$), \mathrm{T}_{\mathrm{k}}=$ treatment effect $(\mathrm{k}=1$ to 12$)$, and $\mathrm{E}_{\mathrm{ijk}}=$ error term.
The model to test for main effect and interaction differences in experiment 2 was;

$$
\begin{gathered}
\mathrm{Y}_{\mathrm{ijklm}}=\mu+\mathrm{C}_{\mathrm{i}}(\mathrm{H})_{\mathrm{k}}+\mathrm{P}_{\mathrm{j}}+\mathrm{H}_{\mathrm{k}}+\mathrm{M}_{\mathrm{l}}+\mathrm{K}_{\mathrm{m}}+(\mathrm{H} \times \mathrm{M})_{\mathrm{kl}} \\
+(\mathrm{H} \times \mathrm{K})_{\mathrm{km}}+(\mathrm{M} \times \mathrm{K})_{\mathrm{lm}}+(\mathrm{H} \times \mathrm{P})_{\mathrm{kj}}+\mathrm{E}_{\mathrm{ijk} \mathrm{m}}
\end{gathered}
$$

Where $\mu$ overall mean, $\mathrm{C}_{\mathrm{i}}(\mathrm{H})_{\mathrm{k}}=$ cow effect nested within hybrid ( $\mathrm{i}=1$ to 12 ), $\mathrm{P}_{\mathrm{j}}=$ period effect $(\mathrm{j}=1$ to 6), $\mathrm{H}_{\mathrm{k}}=$ hybrid effect ( $\mathrm{k}=1$ to 2 ), $\mathrm{M}_{\mathrm{l}}=$ maturity effect (l=1 to 3 ), $\mathrm{K}_{\mathrm{m}}=$ kernel processing effect ( $\mathrm{m}=1$ to 2 ), $(\mathrm{H} \times \mathrm{M})_{\mathrm{kl}}=$ interaction effect of $\mathrm{H}_{\mathrm{k}}$ and $\mathrm{M}_{\mathrm{l}},(\mathrm{H} \times \mathrm{K})_{\mathrm{km}}=$ interaction of $\mathrm{H}_{\mathrm{k}}$ and $\mathrm{K}_{\mathrm{m}},(\mathrm{M} \times \mathrm{K})_{\mathrm{lm}}=$ interaction effect of $\mathrm{M}_{\mathrm{l}}$ and $\mathrm{K}_{\mathrm{m}},(\mathrm{H} \times \mathrm{P})_{\mathrm{kj}}=$ interaction of $\mathrm{H}_{\mathrm{k}}$ and $\mathrm{P}_{\mathrm{j}}$, and $\mathrm{E}_{\mathrm{ijklm}}=$ error term. Significance was declared at $P<$ 0.05 and trends were observed at $P<0.10\left(\mathrm{SAS}^{\circledR}, 1988\right)$.

The model for analyzing repeated measures in experiment 2 was;

$$
\begin{aligned}
& \mathrm{Y}_{\mathrm{ijklmn}}=\mu+\mathrm{C}_{\mathrm{i}}(\mathrm{H})_{\mathrm{k}}+\mathrm{P}_{\mathrm{j}}+\mathrm{H}_{\mathrm{k}}+\mathrm{M}_{\mathrm{l}}+\mathrm{K}_{\mathrm{m}}+(\mathrm{H} \times \mathrm{M})_{\mathrm{kl}} \\
& +(\mathrm{H} \times \mathrm{K})_{\mathrm{km}}+(\mathrm{M} \times \mathrm{K})_{\mathrm{lm}}+(\mathrm{H} \times \mathrm{P})_{\mathrm{kj}}+\mathrm{T}_{\mathrm{n}}+(\mathrm{H} \times \mathrm{T})_{\mathrm{kn}} \\
& +(\mathrm{M} \times \mathrm{T})_{\mathrm{ln}}+(\mathrm{K} \times \mathrm{T})_{\mathrm{mn}}+(\mathrm{H} \times \mathrm{M} \times \mathrm{T})_{\mathrm{kln}}+(\mathrm{H} \times \mathrm{K} \\
& \quad \times \mathrm{T})_{\mathrm{kmn}}+(\mathrm{M} \times \mathrm{K} \times \mathrm{T})_{\mathrm{lmn}}+(\mathrm{P} \times \mathrm{H} \times \mathrm{T})_{\mathrm{jkn}}+\mathrm{E}_{\mathrm{ijklmn}}
\end{aligned}
$$

Where $\mu$ overall mean, $\mathrm{C}_{\mathrm{i}}(\mathrm{H})_{\mathrm{k}}=$ cow nested within hybrid ( $\mathrm{i}=1$ to 12 ), $\mathrm{P}_{\mathrm{j}}=$ period effect $\left(\mathrm{j}=1\right.$ to 6 ), $\mathrm{H}_{\mathrm{k}}=$ hybrid effect ( $\mathrm{k}=1$ to 2$), \mathrm{M}_{1}=$ maturity effect ( $=1$ to $3), \mathrm{K}_{\mathrm{m}}=$ kernel processing effect $(\mathrm{m}=1$ to 2$),(\mathrm{H} \times \mathrm{M})_{\mathrm{kl}}$ = interaction of $\mathrm{H}_{\mathrm{k}}$ and $\mathrm{M}_{\mathrm{l}},(\mathrm{H} \times \mathrm{K})_{\mathrm{km}}=$ interaction of 
$\mathrm{H}_{\mathrm{k}}$ and $\mathrm{K}_{\mathrm{m}},(\mathrm{M} \times \mathrm{K})_{\mathrm{lm}}=$ interaction effect of $\mathrm{M}_{\mathrm{l}}$ and $\mathrm{K}_{\mathrm{m}}$, $(\mathrm{H} \times \mathrm{P})_{\mathrm{kj}}=$ interaction effect of $\mathrm{H}_{\mathrm{k}}$ and $\mathrm{P}_{\mathrm{j}}, \mathrm{T}_{\mathrm{n}}=$ time post feeding ( $\mathrm{n}=1$ to 7$),(\mathrm{H} \times \mathrm{T})_{\mathrm{kn}}=$ interaction effect of $\mathrm{H}_{\mathrm{k}}$ and $\mathrm{T}_{\mathrm{n}},(\mathrm{M} \times \mathrm{T})_{\mathrm{ln}}=$ interaction effect of $\mathrm{M}_{\mathrm{l}}$ and $\mathrm{T}_{\mathrm{n}},(\mathrm{K}$ $\times \mathrm{T})_{\mathrm{mn}}=$ interaction effect of $\mathrm{K}_{\mathrm{m}}$ and $\mathrm{T}_{\mathrm{n}},(\mathrm{H} \times \mathrm{M} \times \mathrm{T})_{\mathrm{kln}}$ = interaction effect of $\mathrm{H}_{\mathrm{k}} \mathrm{M}_{\mathrm{l}}$ and $\mathrm{T}_{\mathrm{n}},(\mathrm{H} \times \mathrm{K} \times \mathrm{T})_{\mathrm{kmn}}=$ interaction effect of $\mathrm{H}_{\mathrm{k}} \mathrm{K}_{\mathrm{m}}$, and $\mathrm{T}_{\mathrm{n}},(\mathrm{M} \times \mathrm{K} \times \mathrm{T})_{\mathrm{lmn}}=$ interaction of $\mathrm{M}_{\mathrm{l}}, \mathrm{K}_{\mathrm{m}}$, and $\mathrm{T}_{\mathrm{n}}$, and $\mathrm{E}_{\mathrm{ijk} k \mathrm{mn}}=$ error term for sub-plot (time) sources of variation. Significance was declared at $P<0.05$ and trends were observed at $P<$ $0.10\left(\mathrm{SAS}^{\circledR}, 1988\right)$.

\section{RESULTS AND DISCUSSION}

\section{Intake and Digestion}

Dry matter and organic matter intake and digestion. Dry matter intake and organic matter (OM) were not affected by hybrid, maturity, or processing of corn silage in experiments 1 and 2 (Table 4). Organic matter truly digested in the rumen was significantly lower $(P<0.01)$ for cows fed diets containing corn silage harvested at one-third ML compared with two-thirds ML in experiment 1 (Table 4). The lower OM digestion may be partially related to reduced digestion of NDF $(P<0.05)$ in the rumen and reduced digestion of fat in the total tract $(P<0.03)$ for cows fed diets containing corn silage harvested at one-third ML compared with two-thirds ML (experiment 1; Johnson et al., 2002b). Organic matter truly digested in the rumen was significantly lower $(P<0.009)$ for cows fed diets containing hybrid Quanta (55.3\%) corn silage compared to hybrid 3845 (58.9\%; Experiment 2; Table 4). The reduction in OM truly digested in the rumen can be partially attributed to a reduction $(P<0.007)$ in NDF digested in the rumen for cows fed diets containing hybrid Quanta corn silage (Johnson et al., 2002b).

Total tract DM and OM digestibilities were significantly greater $(P<0.05)$ for cows fed unprocessed corn silage in experiment 1 , and similar for cows fed processed and unprocessed corn silage based diets in experiment 2 (Table 4). However, there was a trend for increased DM $(P<0.10)$ and $\mathrm{OM}(P<0.14)$ digestion in the total tract for cows fed diets containing processed $(\mathrm{DM}-67.0 \%, \mathrm{OM}-68.8 \%)$ versus unprocessed (DM $65.8 \%, \mathrm{OM}-67.7 \%$ ) corn silage. The authors speculate that in experiment 1 rate of passage may have been the limiting factor for DM and OM digestion, however rate of passage was not measured. The particle size of corn silage in experiment 1 was short (6.4 mm TLC). Therefore, these particles may have been less buoyant in the rumen. The reduction in DM and OM digestibilites for cows fed diets containing processed corn silage in experiment 1 may have been due to the shorter corn silage particles (Johnson et al., 2002a) passing through the rumen faster than the longer unprocessed corn silage particles.

Mertens (1993) reported that feed processing is the second most important factor that affects rate of passage due to decreased particle size or increased density of feed particles. Others (Rojas-Bourrillon et al., 1987) have reported an $8 \%$ decline in ruminal retention time of the solid phase when steers were fed diets containing corn silage that was processed (mean particle length $2.54 \mathrm{~mm}$ ) compared to unprocessed corn silage diets (mean particle length $-3.01 \mathrm{~mm}$ ). Passage rate was also reported to be numerically greater for beef steers (Doggett, 1998) and milk cows (Bal et al., 2000a) fed finely processed corn silage diets, however, the author cautions (Doggett, 1998) that the difference may have been minimized due to restrictions on intake in this study.

Other studies have demonstrated either statistical or numerical responses of processing on ruminal and total tract DM and OM digestibilities. Increases in ruminal DM digestibility due to mechanical processing corn silage have been reported using the macro in situ technique (Doggett, 1998; Harrison et al., 1998; Bal et al., 2000a-fine and medium chop processed). Total tract $\mathrm{DM}$ and $\mathrm{OM}$ digestibilities increased numerically or statistically for cows fed diets that contained corn silage that had been processed (Miller et al., 1969-with screen removed; Young et al., 1998; Weiss and Wyatt, 2000; Bal et al., 2000a-fine and coarse chop processed silages). Others reported no difference in total tract DM (Dhiman et al., 2000-three-fourths ML, Trial 1) or OM (Rojas-Bourrillon et al., 1987) digestibility measurements between cows fed diets containing processed or unprocessed corn silage. While other data (Dhiman et al., 2000, Trial 2) reported a significant decrease in total tract OM digestibility $(P<0.01)$ for cows fed diets containing mechanically processed corn silage (37\% of diet DM) compared to unprocessed corn silage harvested between one-fourth and two thirds ML development. The reduction in total tract OM digestibility can be attributed to the depression in total tract digestibility of NDF and CP (Dhiman et al., 2000).

Nitrogen intake and digestion. Nitrogen truly digested in the rumen $(P<0.03)$ and nitrogen apparently digested in the total tract $(P<0.03)$ were significantly lower for cows fed processed corn silage in experiment 1 , and were similar between cows fed diets containing processed and unprocessed corn silages in experiment 2 (Table 5). Others reported variable results. Total tract CP digestibility was numerically lower for lactating cows fed processed high oil corn silage diets (Weiss and Wyatt, 2000), significantly lower $(P<0.01)$ for lactating cows fed conventional hybrid corn silage diets (Dhiman et al., 2000-Trial 2), and numerically greater when cows 
Table 4. Intake and digestion of DM and OM for cows in experiments 1 and 2 .

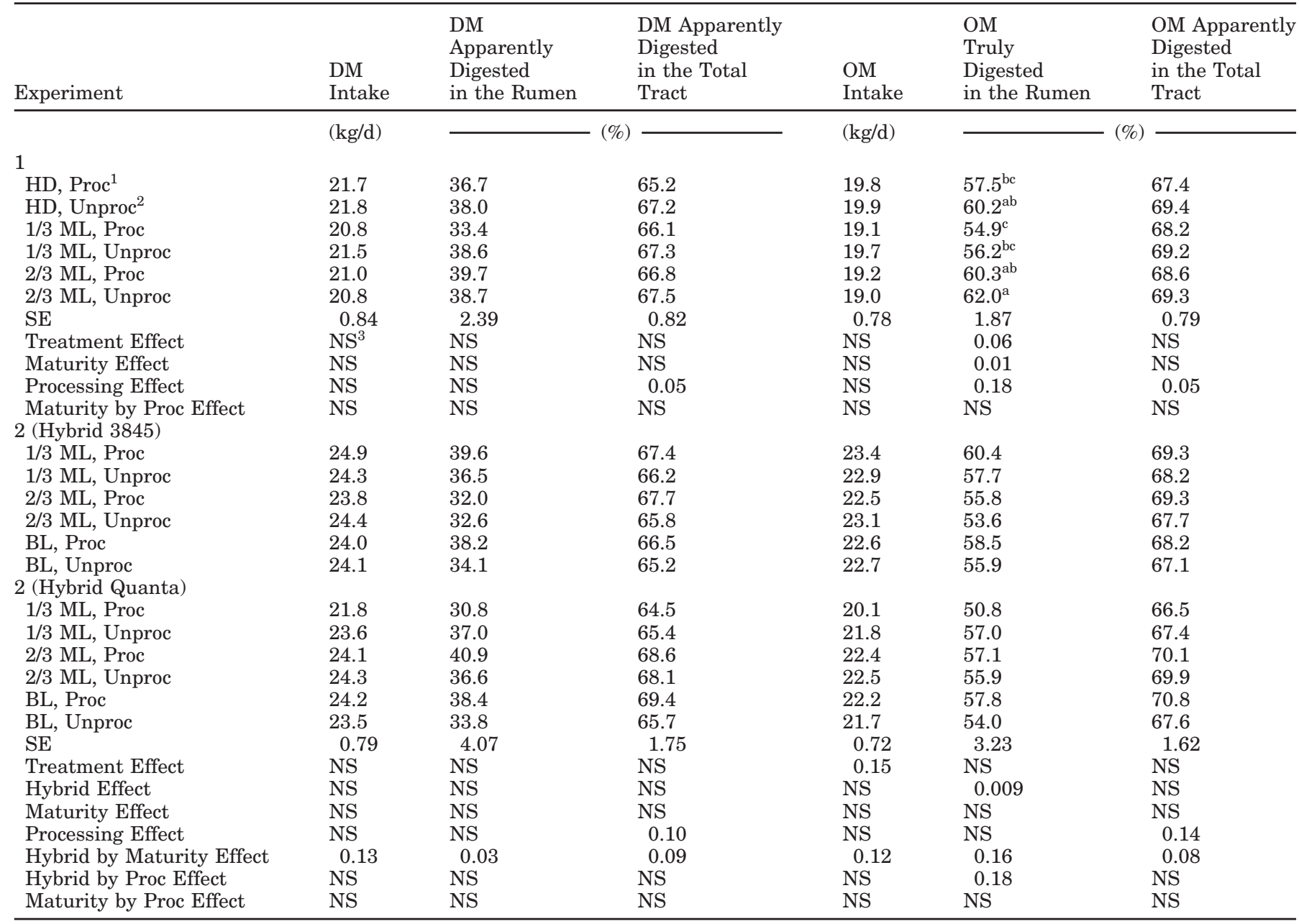

a,b,c $P<0.09$

${ }^{1}$ Proc - Corn silage was harvested with kernel processing rolls set $1 \mathrm{~mm}$ apart.

${ }^{2}$ Unproc - Corn silage was harvested with kernel processing rolls set $15.9 \mathrm{~mm}$ apart.

${ }^{3} \mathrm{NS}-P>0.10$

were fed processed conventional corn silage diets (Young et al., 1998; Bal et al., 2000a-fine and coarse chop; Weiss and Wyatt, 2000).

Nitrogen truly digested in the rumen was significantly greater $(P<0.02)$ for cows fed diets containing corn silage harvested at an advanced maturity (twothirds ML) compared with less mature corn silage (hard dough and one-third ML) in experiment 1 (Table 5). Fiber (NDF) digestion in the rumen was also greater $(P<0.05)$ for cows fed diets containing corn silage harvested at an advanced maturity (two-thirds ML; Johnson et al., 2002b). Greater digestion of fiber and nitrogen in the rumen for cows fed diets containing a mature silage suggests that the environment in the rumen was improved therefore microbes could utilize more of the nutrients present in the diet. Nitrogen digestibility in the total tract was significantly greater $(P<0.01)$ for cows fed diets containing hybrid Quanta (67.6\%) corn silage compared with hybrid 3845 (65.1\%; Table 5). Total tract fiber digestibility was also significantly greater $(P<0.001)$ for hybrid Quanta corn silage (Johnson et al., 2002b). The greater digestion of fiber and nitrogen in the total tract for diets containing hybrid Quanta is due to increased digestion of NDF and nitrogen postruminally because ruminal digestion of NDF and nitrogen tended to be lower compared to hybrid 3845 (Table 5 and Johnson et al., 2002b).

Digestion of DM, OM, and nitrogen in the small intestine and large intestine and cecum. In experiment 1 and for hybrid Quanta in experiment 2, ileal digesta was collected to evaluate trends observed in $\mathrm{DM}, \mathrm{OM}$, and $\mathrm{N}$ metabolism due to site of digestion 
Table 5. N Intake, Balance, and Digestibility in experiments 1 and 2.

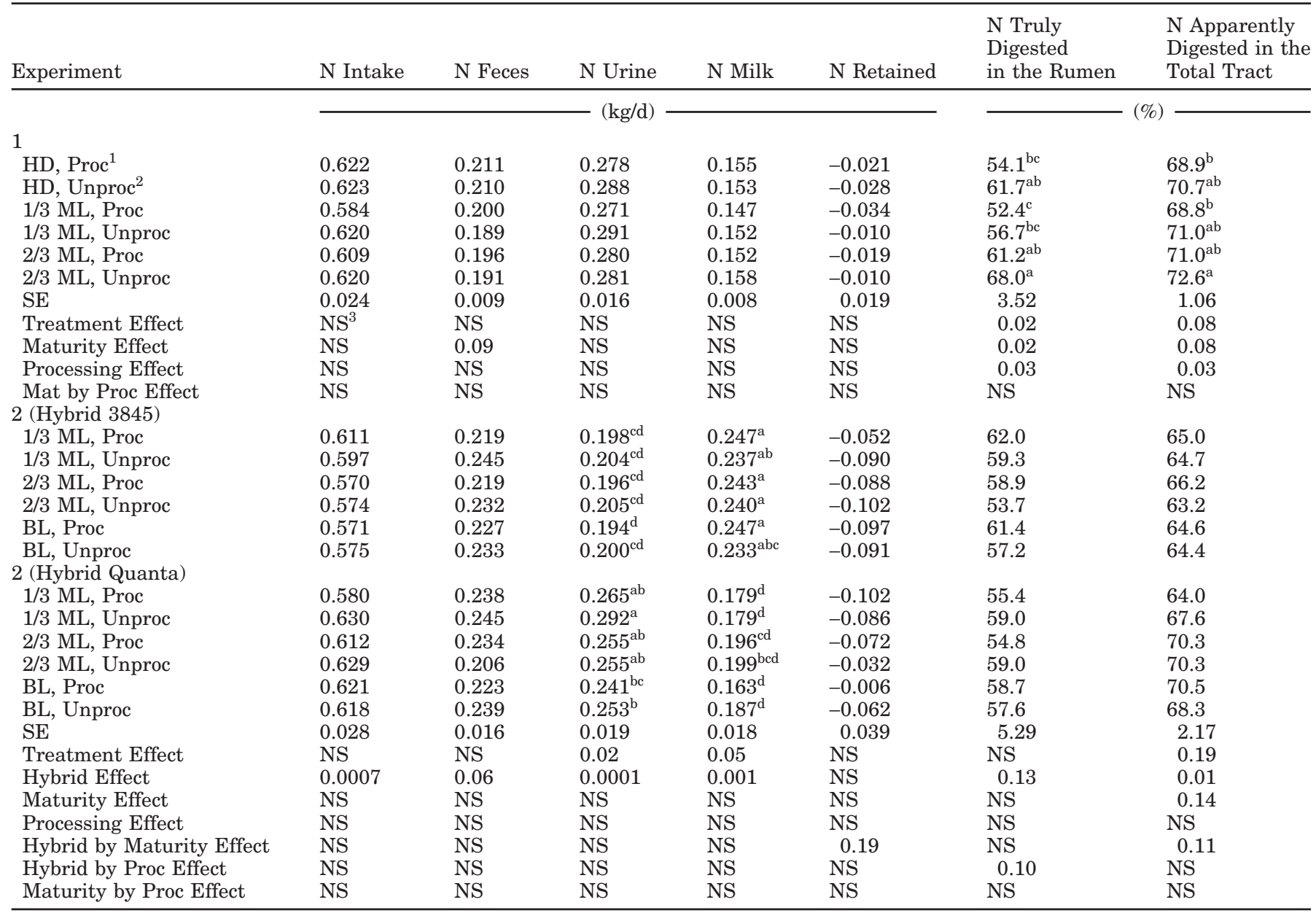

${ }^{\mathrm{a}, \mathrm{b}, \mathrm{c}} P \leq 0.09$.

${ }^{1}$ Proc - Corn silage harvested with kernel processing rolls set $1 \mathrm{~mm}$ apart.

${ }^{2}$ Unproc - Corn silage harvested with kernel processing rolls set $15.9 \mathrm{~mm}$ apart.

${ }^{3} \mathrm{NS}-P>0.10$.

(small intestine vs. large intestine and cecum) for cows fed corn silage based diets. These data should be interpreted with caution due to the lack of replication of treatment within an experiment. The majority of DM digestion (\% of intake) occurred in the rumen (approximately 31 to $41 \%$; Table 4 ) versus the small intestine (approximately 21 to $40 \%$ Table 6), or large intestine and cecum (approximately 0 to $15 \%$; Table 6 ). Trends in DM digestibility in the small intestine (Table 6) between treatments were similar to trends observed with total tract DM digestibility (Table 4). In experiment 1 , DM digestibility in the small intestine (Table 6) was greater for cows fed unprocessed corn silage diets, and in experiment $2, \mathrm{DM}$ digestion tended to be greater for cows fed processed corn silage harvested at the advanced maturities (two-thirds ML and BL). The amount of DM digestion, as a percent of intake, that occurred in the lower bowel was minimal (Table 6).
Organic matter that was truly digested in the small intestine and large intestine and cecum was evaluated (Table 6). There was decreased digestion of OM in the small intestine for cows fed processed corn silage based diets at an advanced maturity (two-thirds ML) in experiment 1, and increased digestion for cows fed processed corn silage based diets at one-third and two-thirds ML compared to cows fed unprocessed corn silage based diets in experiment 2. Overall, when the TMR was more digestible in the rumen, there was more digestion in the small intestine.

Apparent digestion of $\mathrm{N}$ in the small intestine (between duodenum and ileum) was typically between 56 and $64 \%$ (Table 6). This was similar to others ( $\mathrm{n}=$ 12) that report approximately $65 \%$ of nonammonia $\mathrm{N}$ (NAN) passing to the duodenum was apparently digested in the small intestine (Ruminant Nitrogen Usage, 1985). There was limited apparent digestion of $\mathrm{N}$ 
Table 6. Intake and digestion of DM, OM, and N postruminally. ${ }^{1}$

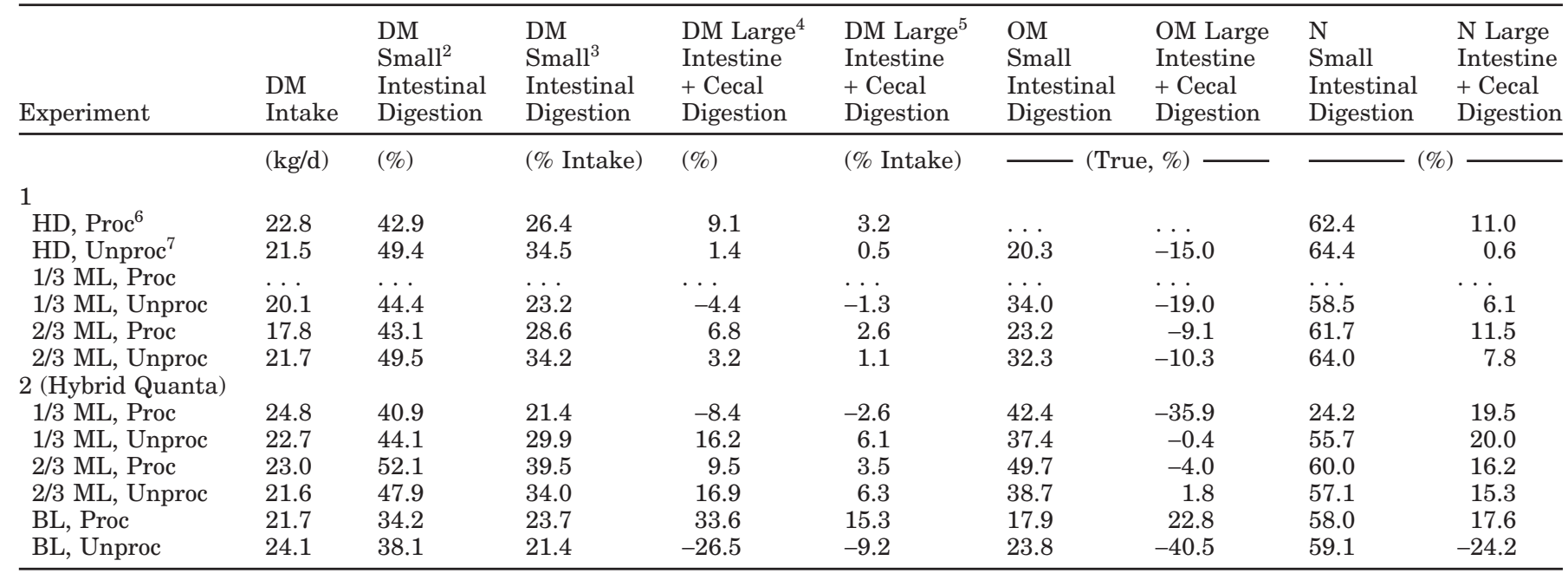

${ }^{1}$ Digestion estimates were measured postruminally using a ruminally, duodenally, and ileally cannulated lactating Holstein cow in two experiments.

${ }^{2}$ Small intestinal digestion - [(Passage to Duodenum - Passage to Ileum)/Passage to Duodenum $] \times 100$.

${ }^{3}$ Small intestinal digestion (\% of Intake) - [(Passage to Duodenum - Passage to Ileum)/Intake $] \times 100$.

${ }^{4}$ Large intestine + cecal digestion $-[($ Passage to Ileum - Passage to Feces $) /$ Passage to Ileum $] \times 100$.

${ }^{5}$ Large intestine + cecal digestion $(\%$ of Intake $)-[$ (Passage to Ileum - Passage to Feces)/Intake] $\times 100$.

${ }^{6}$ Proc - Corn silage was harvested with kernel processing rolls set $1 \mathrm{~mm}$ apart.

${ }^{7}$ Unproc - Corn silage was harvested with kernel processing rolls set $15.9 \mathrm{~mm}$ apart.

(1 and 20\%) in the large intestine and cecum (Table 6). A greater percentage of $\mathrm{N}$ digestion occurred in the large intestine and cecum for hybrid Quanta in experiment 2 . This may be partially related to more structural carbohydrates (fiber) being present in the large intestine to provide an energy source for microbial digestion. There was also a greater amount of $\mathrm{N}$ passing into the feces for hybrid Quanta in experiment 2 compared to experiment 1 (data not shown), indicating that there may have been some microbial synthesis of protein in the large intestine and cecum that was excreted in the feces (metabolic fecal N).

\section{Nitrogen Balance}

Nitrogen excreted in the urine was significantly lower $(P<0.0001)$ for cows fed diets containing hybrid 3845 corn silage compared to hybrid Quanta corn silage (Table 5). The lower $\mathrm{N}$ excretion in the urine was partially related to lower urine output $(P<0.0001)$. However, $\mathrm{N}$ secreted in the milk was significantly greater $(P<0.001)$ for cows consuming diets containing hybrid 3845 corn silage (Table 5). The greater secretion of $\mathrm{N}$ in the milk was related to a greater milk nitrogen concentration $(P$ $<0.0002$ ) for cows consuming diets containing hybrid 3845 corn silage compared to hybrid Quanta corn silage (see Table 10).

In all experiments, cows were in a negative $\mathrm{N}$ balance (Table 5). Cows were close to being in $\mathrm{N}$ balance in experiment 1. Nitrogen removed from tissues varied from 10 to $34 \mathrm{~g} / \mathrm{d}$ (Table 5). The CP concentration of the diets in experiment 1 varied from 17.7 to $18.5 \%$ and was adequate to meet the $\mathrm{N}$ requirements of the cows (Table 2). However, in experiment 2 , cows were in a much greater negative $\mathrm{N}$ balance (Table 5). Nitrogen removed from tissues varied from 6 to $102 \mathrm{~g} / \mathrm{d}$ (Table 5). The concentration of $\mathrm{CP}$ provided in these diets was low, and ranged from 14.7 to $16.5 \%$ (Table 3 ). The quality of the alfalfa hay and whole cottonseed that was provided for cows consuming diets containing hybrid 3845 during experiment 2 was much lower than anticipated when the diets were originally balanced (Johnson et al., 2002a). Protein levels were low for the alfalfa hay and whole cottonseed, and NDF and ADF levels were high in the alfalfa hay for hybrid 3845 in experiment 2 (Johnson et al., 2002a). Crude protein levels were greater for hybrid Quanta in experiment 2 because the quality of alfalfa hay and whole cottonseed were greater, however the levels were not great enough to meet the $\mathrm{N}$ requirements of the cows (Johnson et al., 2002a; Table 5).

\section{N Metabolism}

In experiment 1 , microbial $\mathrm{N}$ as a percent of total nitrogen was lower $(P<0.08)$ for cows fed diets containing corn silage harvested at one-third ML compared to hard dough and two-thirds ML (Table 7). The lower 
Table 7. Flow of $\mathrm{N}$ fractions to the duodenum and microbial $\mathrm{N}$ efficiency in cows in experiments 1 and 2.

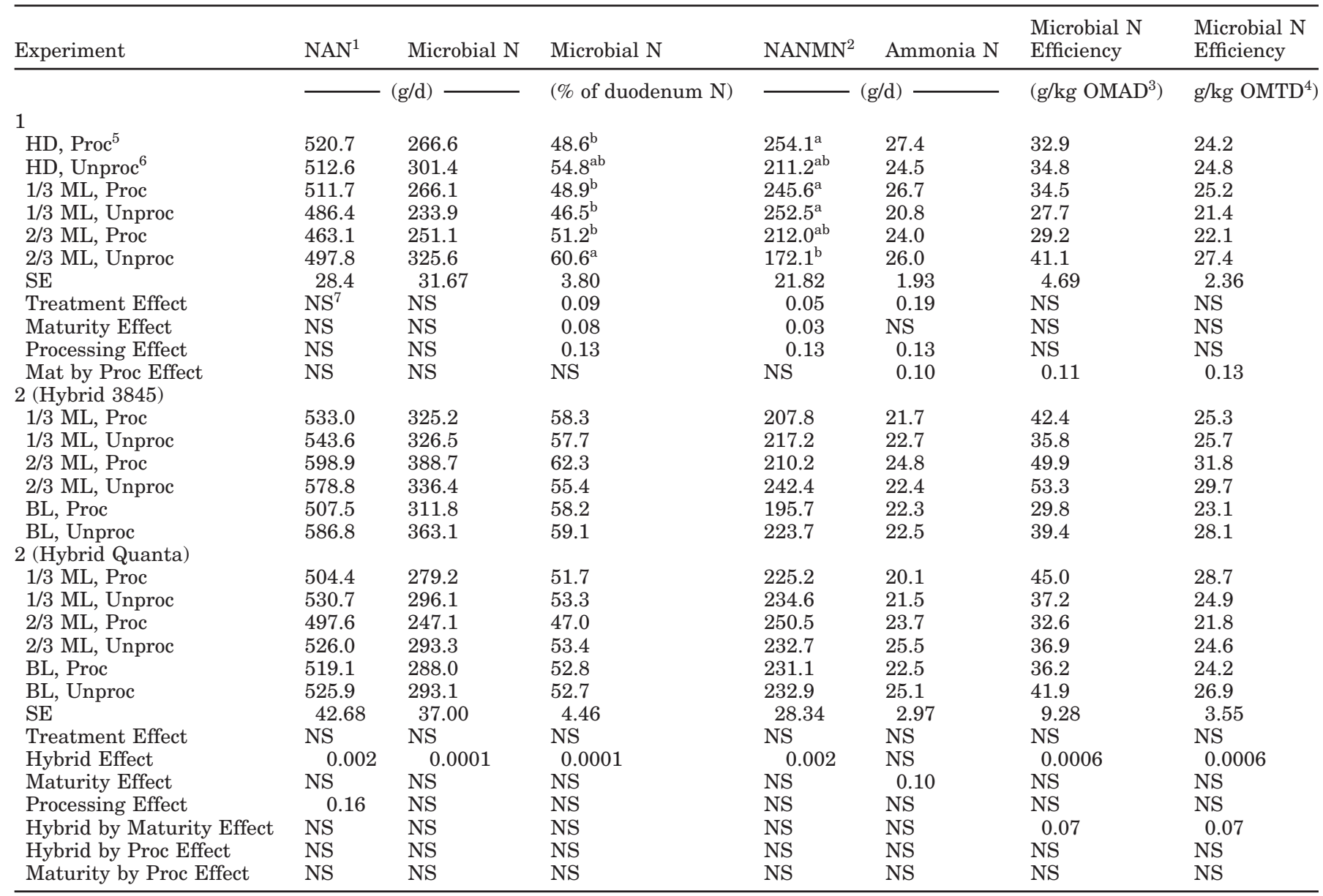

${ }^{\mathrm{a}, \mathrm{b}} P \leq 0.09$.

${ }^{1} \mathrm{NAN}$ - Nitrogen from microbial and feed sources.

${ }^{2}$ NANMN - Nonammonia, nonmicrobial N; $\mathrm{N}$ from feed sources.

${ }^{3} \mathrm{OMAD}$ - Organic matter apparently digested.

${ }^{4}$ OMTD - Organic matter truly digested.

${ }^{5}$ Proc - Corn silage was harvested with kernel processing rolls set $1 \mathrm{~mm}$ apart.

${ }^{6}$ Unproc - Corn silage was harvested with kernel processing rolls set $15.9 \mathrm{~mm}$ apart.

${ }^{7} \mathrm{NS}-P>0.10$.

production of microbial $\mathrm{N}$ at one-third $\mathrm{ML}$ lead to greater flow $(P<0.03)$ of feed $\mathrm{N}(\mathbf{N A N M N})$ from the duodenum for cows fed diets containing corn silage harvested at one-third ML (Table 7). Microbial nitrogen flow (MNF; g/d; $P<0.0001$ ) was significantly greater and feed N (NANMN; $P<0.002)$ was significantly lower for cows fed diets containing hybrid 3845 corn silage compared with cows fed diets containing hybrid Quanta corn silage. The greater flow of microbial nitrogen from the rumen for cows consuming hybrid 3845 corn silage based diet may have been partially related to greater $(P<0.0001)$ production of microbial $\mathrm{N}$ in the rumen and greater $(P<0.002)$ flow of NAN to the duodenum (Table 7).
Total $\mathrm{N}$ flow to the duodenum increased as OM intake increased $\left(\mathrm{R}^{2}=0.28 ; P<0.02\right)$ for cows fed processed and unprocessed corn silage based diets (Figure 1a). Nonammonia $\mathrm{N}\left(\mathrm{R}^{2}=0.30 ; P<0.02\right)$ and microbial $\mathrm{N}$ $\left(\mathrm{R}^{2}=0.14 ; P<0.12\right)$ flow to the duodenum increased as OM intake increased for cows fed processed and unprocessed corn silage diets (Figures $1 \mathrm{~b}$ and 1c). These results were similar to trends observed in data compiled from the literature (Clark et al., 1992) that demonstrated that total N, NAN, and MNF to the duodenum increased as $\mathrm{OM}$ intake increased. Although this data follows trends observed in the literature it should be noted that there is an area in the plots in Figure 1 where there were no data points. There were many 

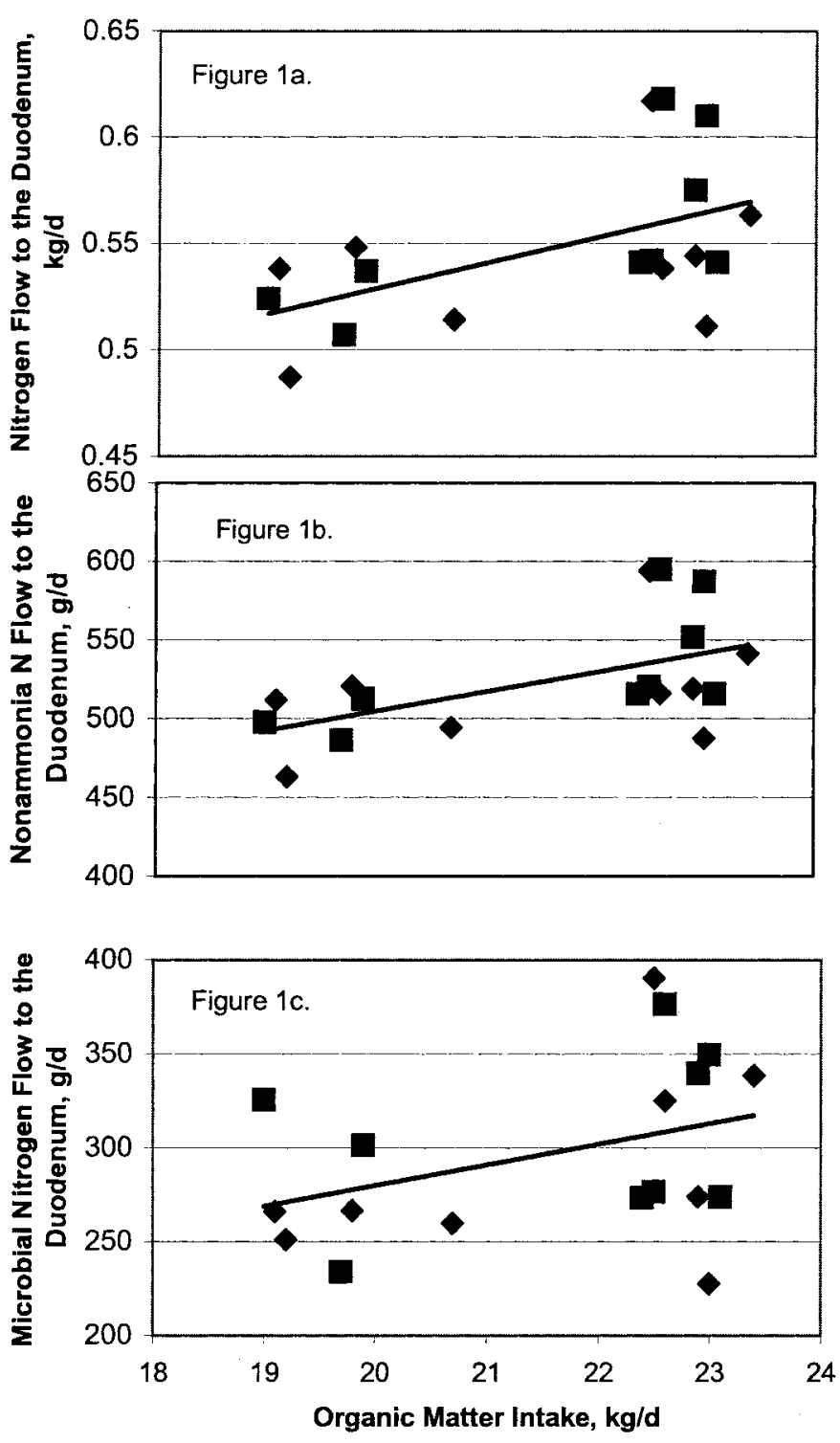

Figure 1. Effect of organic matter intake on nitrogen flow (Figure 1a), nonammonia nitrogen flow (Figure 1b), and microbial nitrogen flow (Figure 1c) to the duodenum for cows fed mechanically processed $(\checkmark)$ and unprocessed (ם) corn silage based diets. Each data point represents a mean for each treatment in experiments 1 and 2 . Figure $1 \mathrm{a}: \mathrm{Y}=0.0119 \mathrm{x}+0.2900, \mathrm{R}^{2}=0.2818, P<0.02$. Figure $1 \mathrm{~b}: \mathrm{Y}=12.2961 \mathrm{x}$ $+258.60, \mathrm{R}^{2}=0.2973, P<0.02$. Figure $1 \mathrm{c}: \mathrm{Y}=11.0033 \mathrm{x}+59.8345$, $\mathrm{R}^{2}=0.1434, P<0.12$.

other factors that must have influenced microbial $\mathrm{N}$ production in the rumen besides OMI. Others have reported that DMI, OMI, TDN intake, digestible energy intake, OM digested in the rumen and total tract, and forage and concentrate intake are all factors that influence microbial $\mathrm{N}$ yield (Ruminant Nitrogen Usage, 1985).

Microbial $\mathrm{N}$ efficiency was greater $(P<0.0006)$ for cows fed diets containing hybrid 3845 corn silage com-
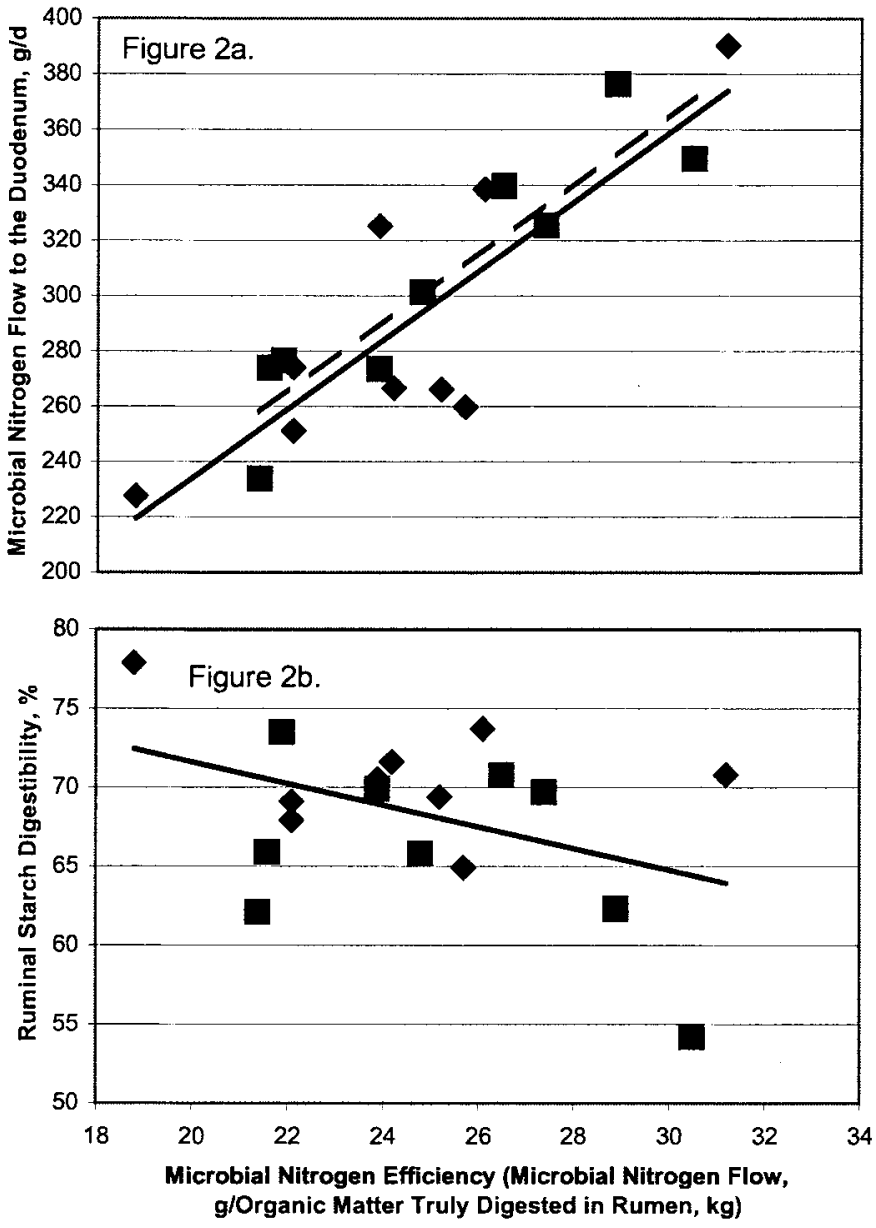

Figure 2. Effect of microbial nitrogen efficiency on microbial nitrogen flow to the duodenum (Figure 2a) and ruminal starch digestibility (Figure $2 b$ ) for cows fed mechanically processed $(\diamond)$ or unprocessed (ם) corn silage based diets. Each data point represents a mean for each treatment in experiments 1 and 2. Figure 2a: Processed (-), Y $=12.469 \mathrm{x}-15.07, \mathrm{R}^{2}=0.6836, P<0.006$. Unprocessed $(---), \mathrm{Y}=$ $12.539 \mathrm{x}-10.485, \mathrm{R}^{2}=0.8408, P<0.0005$. Figure $2 \mathrm{~b}: \mathrm{Y}=-0.6856 \mathrm{x}+$ $85.329, \mathrm{R}^{2}=0.1815, P<0.08$.

pared to hybrid Quanta corn silage (experiment 2; Table 7). The increase in microbial $\mathrm{N}$ efficiency was related to increased microbial $\mathrm{N}$ flow and increased OM truly digested in the rumen. Microbial $\mathrm{N}$ efficiency (microbial $\mathrm{N}$ synthesized per kg OM truly fermented) had a linear relationship with microbial $\mathrm{N}$ flow and ruminal starch digestibility (Figures 2a and 2b). As microbial N efficiency increased microbial $\mathrm{N}$ flow increased (processed, $\mathrm{R}^{2}=0.68, P<0.006$; unprocessed, $\mathrm{R}^{2}=0.84, P<0.0005$; Figure 2a). Microbial $\mathrm{N}$ efficiency tended to decrease as ruminal starch digestibility increased $\left(\mathrm{R}^{2}=0.18 ; P\right.$ $<0.08$ ) for cows fed corn silage based diets (Figure 2b). This suggests that the amount of $\mathrm{N}$ present in the TMR and rate of digestion of $\mathrm{N}$ were not synchronized with starch and other carbohydrate sources in the rumen 

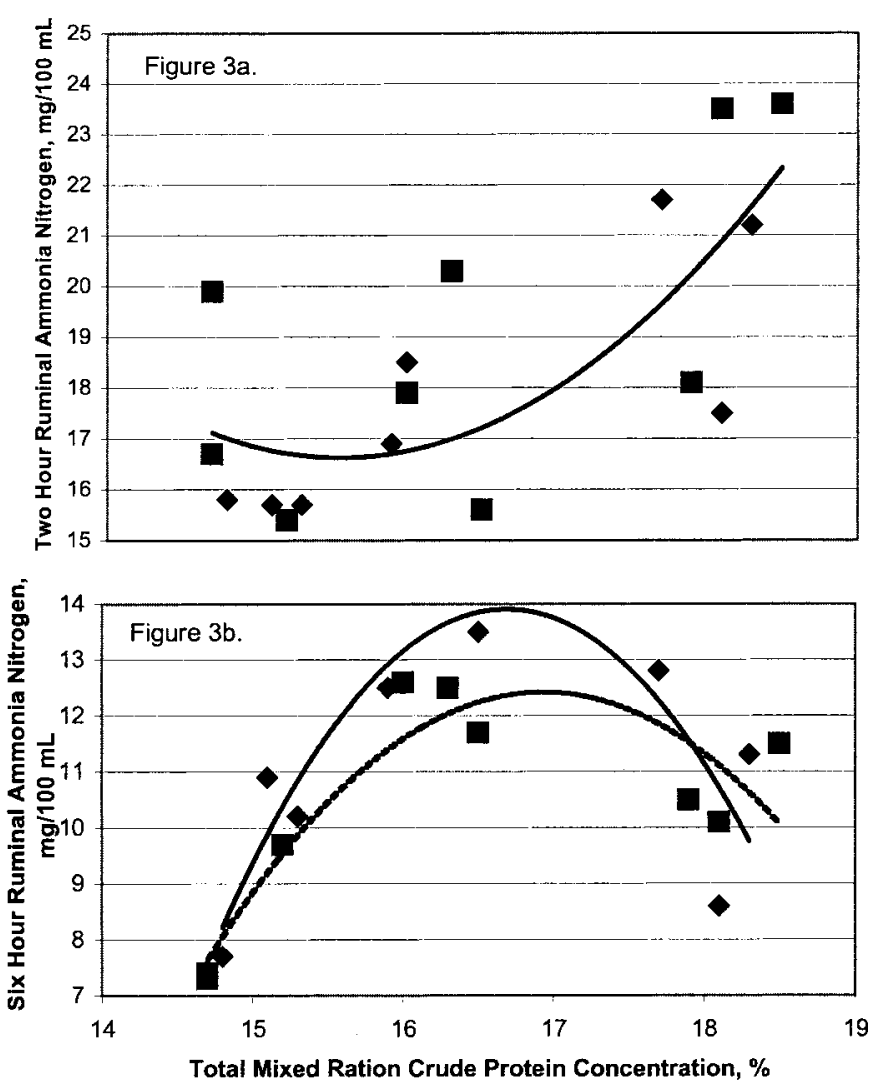

Figure 3. Effect of the concentration of crude protein in the total mixed ration on ruminal ammonia concentration $2 \mathrm{~h}$ after feeding (Figure $3 \mathrm{a}$ ) and $6 \mathrm{~h}$ after feeding (Figure $3 \mathrm{~b}$ ) for cows fed mechanically processed ( ) or unprocessed ( $\mathbf{\square}$ ) corn silage based diets. Each data point represents a mean for each treatment in experiments 1 and 2 . Figure 3a: $\mathrm{Y}=0.660 \mathrm{x}^{2}-20.536 \mathrm{x}+176.391, \mathrm{R}^{2}=0.5095, P<0.005$. Figure 3b: Processed (-), $\mathrm{Y}=-1.5962 \mathrm{x}^{2}+53.273 \mathrm{x}-430.6, \mathrm{R}^{2}=0.735$, $P<0.02$. Unprocessed (---), $\mathrm{Y}=-0.9612 \mathrm{x}^{2}+32.554 \mathrm{x}-263.21, \mathrm{R}^{2}=$ $0.8128, P<0.007$.

when digestibility increased which lead to uncoupling of energy and protein within the rumen, therefore, limiting microbial $\mathrm{N}$ efficiency.

\section{Ruminal Measures}

Ruminal ammonia nitrogen. Crude protein concentrations of the TMR were quadratically related to ruminal ammonia $\mathrm{N}$ concentrations 2 and $6 \mathrm{~h}$ after feeding (Figures $3 \mathrm{a}$ and $3 \mathrm{~b}$ ). As the $\mathrm{CP}$ concentration of the TMR increased, ruminal ammonia $\mathrm{N} 2 \mathrm{~h}$ after feeding increased $\left(\mathrm{R}^{2}=0.51 ; P<0.005\right)$ for cows fed the processed and unprocessed corn silage diets, and the slope for the linear part of the equation was negative (Figure 3a). Crude protein concentration of the TMR explained $73.5(P<0.02)$ and $81.3 \%(P<0.007)$ of the variation in ruminal ammonia $\mathrm{N}$ levels $6 \mathrm{~h}$ after feeding for cows fed processed and unprocessed corn silage diets, respectively (Figure $3 \mathrm{~b}$ ).
Ruminal ammonia $\mathrm{N}$ concentrations $6 \mathrm{~h}$ after feeding increased 4 to $6 \mathrm{mg} / 100 \mathrm{ml}$ as the $\mathrm{CP}$ concentration of the TMR increased from approximately14.5 to $16.5 \%$, and then ruminal ammonia $\mathrm{N}$ concentrations declined as $\mathrm{CP}$ concentration increased to $18.5 \%$ (Figure $3 \mathrm{~b}$ ). The quadratic relationship between $\mathrm{CP}$ concentration in the TMR and $6 \mathrm{~h}$ ruminal ammonia $\mathrm{N}$ concentration may have been related to the availability of protein and carbohydrate sources in the rumen prior to $6 \mathrm{~h}$. When the concentration of CP in the TMR was extremely low (approximately 14.5\%), there was low ammonia N production, and as CP concentration increased to $16.5 \%$ ammonia $\mathrm{N}$ increased. However the carbohydrate sources were not readily available indicating that protein and carbohydrates were uncoupled, and ammonia $\mathrm{N}$ levels remained high in the rumen. At greater levels of CP concentration in the TMR, there was lower ammonia $\mathrm{N} 6 \mathrm{~h}$ after feeding indicating that protein and carbohydrate sources were synchronized and microbial $\mathrm{N}$ was synthesized. Although in many incidences there was slightly more ammonia $\mathrm{N}$ remaining in the rumen $6 \mathrm{~h}$ after feeding when cows were fed processed diets, the total amount of ammonia remaining was reduced by about one-half. This indicates that, by $6 \mathrm{~h}$ after feeding, the majority of ammonia $\mathrm{N}$ was utilized in the synthesis of microbial protein, absorbed across the rumen wall, or passed into the duodenum as free ammonia N.

Dietary CP concentrations and ruminal ammonia $\mathrm{N}$ levels $2 \mathrm{~h}$ after feeding were greater in experiment 1 than in experiment 2 , because in experiment 2 there was lower dietary CP levels and ruminal ammonia $\mathrm{N}$ formation (Table 8). These results were typical to results observed by Aldrich et al. (1993). Ruminal ammonia $\mathrm{N}$ levels were greater, on average, in experiments 1 and 2 than $5 \mathrm{mg} / \mathrm{dl}$, therefore it has been suggested that less than optimal microbial protein synthesis occurred (Satter et al., 1974).

Ruminal $\boldsymbol{p H}$. Maturity of corn silage affected $\mathrm{pH}$ concentration in the rumen over time in experiment 1 , but not in experiment 2 . In experiment 1 , the $\mathrm{pH}$ level in the rumen tended to differ between maturities $1 \mathrm{~h}$ prior to feeding and 1 and $4 \mathrm{~h}$ after feeding (Figure 4a). Ruminal pH $1 \mathrm{~h}$ prior to feeding $(P<0.0003$ and $P<$ 0.009 , respectively) and $4 \mathrm{~h}$ after feeding $(P<0.06$ and $P<0.12$ ) were lower for cows fed diets containing corn silage harvested at hard dough and two-thirds ML compared to one-third ML (experiment 1; Figure 4a). Ruminal pH $1 \mathrm{~h}$ after feeding $(P<0.006$ and $P<0.03$, respectively) was also lower for cows fed diets containing corn silage harvested at hard dough compared to one-third ML and two-thirds ML (experiment 1; Figure 4a). These differences in ruminal $\mathrm{pH}$ between maturities in experiment 1 may have had an influence on ruminal fiber 
Table 8. Rumen fluid ammonia N, acetate, propionate, and butyrate concentrations, and A:P ratio 2 and $6 \mathrm{~h}$ after feeding in experiments 1 and 2 .

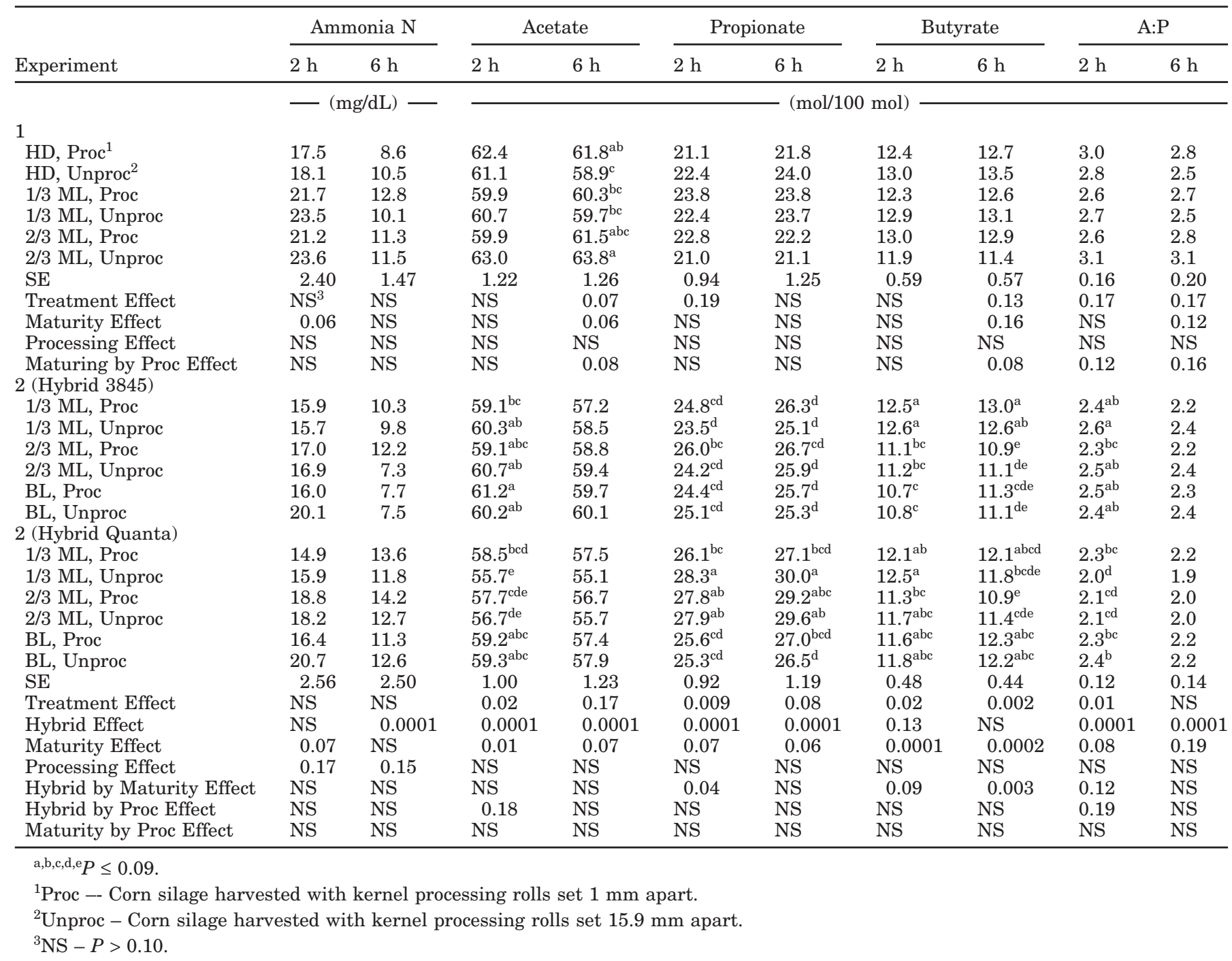

digestion. Digestion of fiber in the rumen was lower for cows fed diets containing corn silage harvested at hard dough and one-third ML, and ruminal $\mathrm{pH}$ for cows fed diets containing corn silage harvested at hard dough tended to be lower than diets containing corn silage harvested at one-third ML and two-thirds ML $1 \mathrm{~h}$ after feeding.

The ruminal $\mathrm{pH}$ level at every hour after feeding for 6 consecutive $\mathrm{h}$ was contrasted to the $\mathrm{pH}$ level $1 \mathrm{~h}$ prior to feeding. Both experiments demonstrated a significant decline $(P<0.0001)$ in ruminal $\mathrm{pH}$ after feeding compared to $1 \mathrm{~h}$ prior to feeding. The hour by maturity interaction between $1 \mathrm{~h}$ prior to feeding and $2(P<$ $0.005), 3(P<0.08), 5(P<0.04)$, and $6(P<0.01) \mathrm{h}$ after feeding was significant in experiment 1 (Figure $4 a$ ).

Mechanical processing of corn silage affected $\mathrm{pH}$ in the rumen over time in experiment $2(P<0.09$; Figure
$4 \mathrm{~b}$ ), but not in experiment 1 . In experiment 2 , cows fed diets containing processed corn silage tended to have lower ruminal pH levels $1(P<0.11), 2(P<0.10), 4(P$ $<0.15)$, and $5(P<0.15) \mathrm{h}$ after feeding compared to cows fed diets containing unprocessed corn silage (Figure $4 \mathrm{~b}$ ). Some studies have reported no significant difference due to processing corn silage on rumen $\mathrm{pH}$ (Doggett, 1998; Rohr et al., 1986; and Jirovec et al., 1998; Bal et al., 2000a), while others have reported a significant decrease at $4 \mathrm{~h}$ after feeding (Rojas-Bourrillon et al., 1987), and when data was summarized across multiple timepoints (Dhiman et al., 2000).

Hybrid of corn silage fed in the diet significantly affected $(P<0.002)$ ruminal $\mathrm{pH}$ over time (Figure $4 \mathrm{c})$. Cows fed diets containing hybrid Quanta corn silage had lower ruminal pH $2(P<0.0001), 3(P<0.004), 5$ $(P<0.01)$, and $6(P<0.0004) \mathrm{h}$ after feeding than cows 

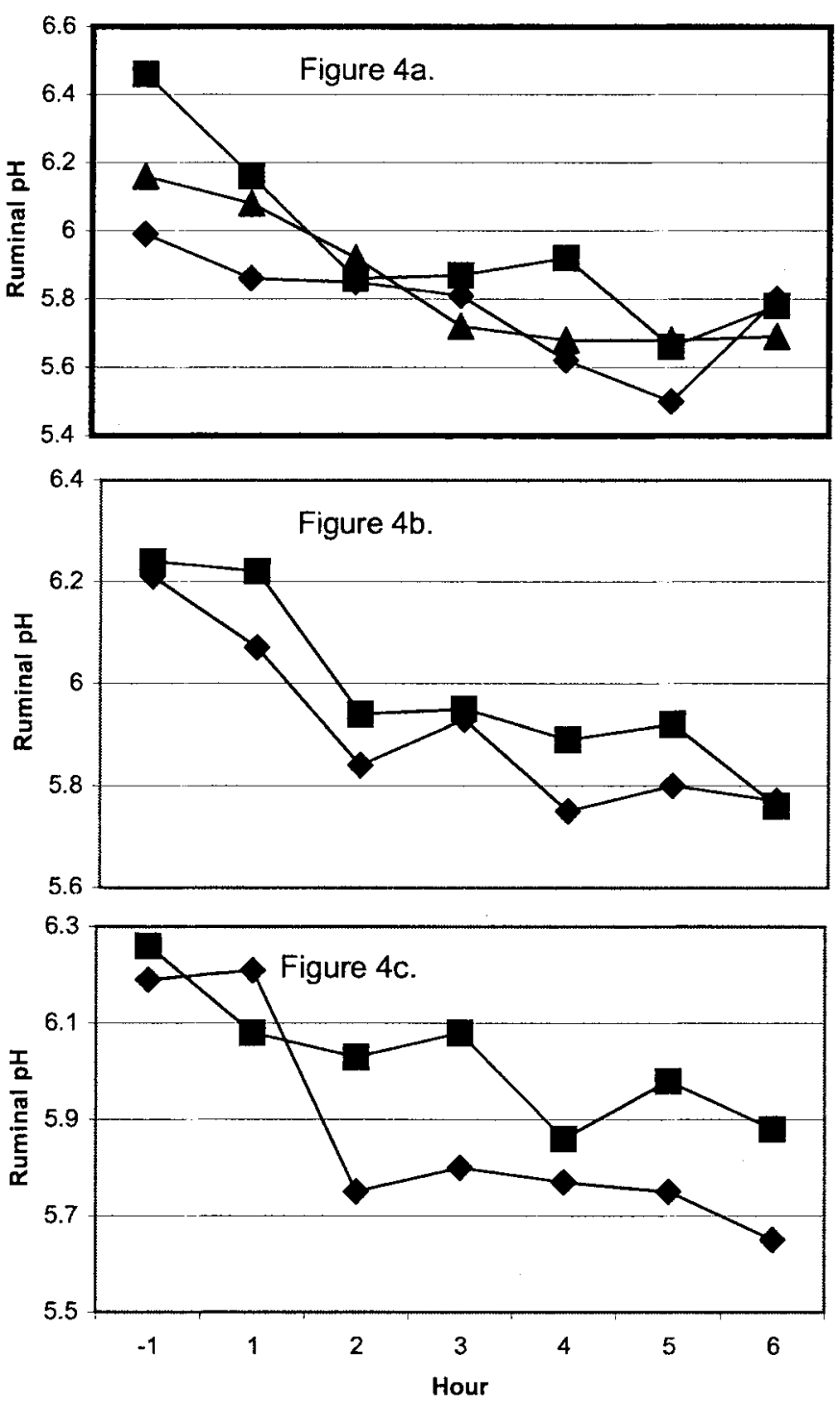

Figure 4. Ruminal $\mathrm{pH}$ relative to time of feeding for cows fed corn silage based diets that differed in maturity [Figure 4a; Experiment 1 - hard dough ( ), one-third milkline (ם), and two-thirds milkline $(\boldsymbol{\Delta})$ ], processing method [Figure $4 \mathrm{~b}$; Experiment $2-$ processed $(\bullet$ and unprocessed (ם), and hybrid [Figure 4c; Experiment 2 - hybrid Quanta $(\bullet)$ and hybrid $3845(\boldsymbol{\square})]$.

fed diets containing hybrid 3845 corn silage (Figure 4c). There was also a significant hour by hybrid interaction $(P<0.0003)$ when the ruminal $\mathrm{pH}$ at every hour after feeding for 6 consecutive $\mathrm{h}$ was contrasted to the $\mathrm{pH}$ level $1 \mathrm{~h}$ prior to feeding. The ruminal $\mathrm{pH} 1(P<0.05)$, $2(P<0.03), 3(P<0.08), 4(P<0.09), 5(P<0.08)$, and $6(P<0.11) \mathrm{h}$ after feeding tended to be lower than ruminal $\mathrm{pH} 1 \mathrm{~h}$ prior to feeding for both hybrids, except for hybrid Quanta $1 \mathrm{~h}$ after feeding (Figure 4c).

Ruminal $\mathrm{pH}$ tended to decline at a slower rate for cows fed hybrid 3845 corn silage diets compared to cows fed hybrid Quanta corn silage based diets in experiment 2 . There were two main factors that contributed to the differences in rate of ruminal $\mathrm{pH}$ decline. Data from ruminal in situ incubations of the corn silages used in experiment 2 suggested that hybrid Quanta (76.8) has a greater amount of starch disappearance by $8 \mathrm{~h}$ after feeding compared to hybrid 3845 (experiment 2, 61.6\%; data not presented). Also, cows fed hybrid Quanta diets had greater $(P<0.002)$ starch intake than cows fed hybrid 3845 diets (Johnson et al., 2002b). The greater amount of starch and the faster rate of starch degradation in the rumen both influenced the rapid decline in ruminal $\mathrm{pH}$ for cows fed diets containing hybrid Quanta in experiment 2. Other studies have indicated a rapid decline in ruminal $\mathrm{pH}$ when high levels of ruminally available NSC were fed (Aldrich et al., 1993).

The rapid decline in ruminal $\mathrm{pH}$ from approximately 6.2 to 5.7 for cows fed diets containing hybrid Quanta corn silage was an indication that fiber digestion in the rumen was limited. Cellulose digesting bacteria work best if the $\mathrm{pH}$ in the rumen is 6.7 (Van Soest, 1994). If ruminal $\mathrm{pH}$ declines below 6.2 there is a lag time before fiber digestion begins (Van Soest, 1994). The rapid decline in ruminal $\mathrm{pH}$ below 6.2 may have contributed to limited ruminal digestion of $\mathrm{NDF}(P<0.007)$ for hybrid Quanta in experiment $2(34.3 \%)$ compared with hybrid 3845 (40.6\%; Johnson et al., 2002b).

Ruminal volatile fatty acids. Ruminal VFA and lactic acid concentrations were measured 2 and $6 \mathrm{~h}$ after feeding (Tables 8 and 9). In experiment 2 , acetate concentrations were significantly lower $(P<0.0001$ and $P<0.0001)$ and propionate concentrations were significantly greater $(P<0.0001$ and $P<0.0001)$ for cows fed diets containing hybrid Quanta (acetate - 57.7 and 56.0, propionate -27.3 and 29.1) compared to hybrid 3845 (acetate -60.4 and 59.5, propionate -23.9 and 25.0 ) corn silages 2 and $6 \mathrm{~h}$ after feeding, respectively (Table $8)$. The acetate to propionate ratio was also greater $(P$ $<0.0001$ and $P<0.0001)$ for cows fed diets containing hybrid 3845 (2.5 and 2.4) compared to hybrid Quanta (2.1 and 2.0) corn silage 2 and $6 \mathrm{~h}$ after feeding, respectively, in experiment 2 (Table 8). These trends suggest that there was a slight shift in the microbial population from fiber digesters for diets containing hybrid 3845 to starch digesters for diets containing hybrid Quanta in experiment 2. Propionate is the major end product of microbial fermentation when nonfiber carbohydrates (starch) make up a greater portion of the diet because the microbes present use the acrylate pathway that directly synthesizes propionate from pyruvate (Van Soest, 1994). The low acetate to propionate ratio for hybrid Quanta in experiment 2 indicates that there was a substantial amount of rapidly fermentable carbohydrates in the rumen. Therefore, even though the rough- 
Table 9. Rumen fluid isobutyrate, isovalerate, valerate, lactate, and total VFA concentrations 2 and $6 \mathrm{~h}$ after feeding in cows in experiments 1 and 2 .

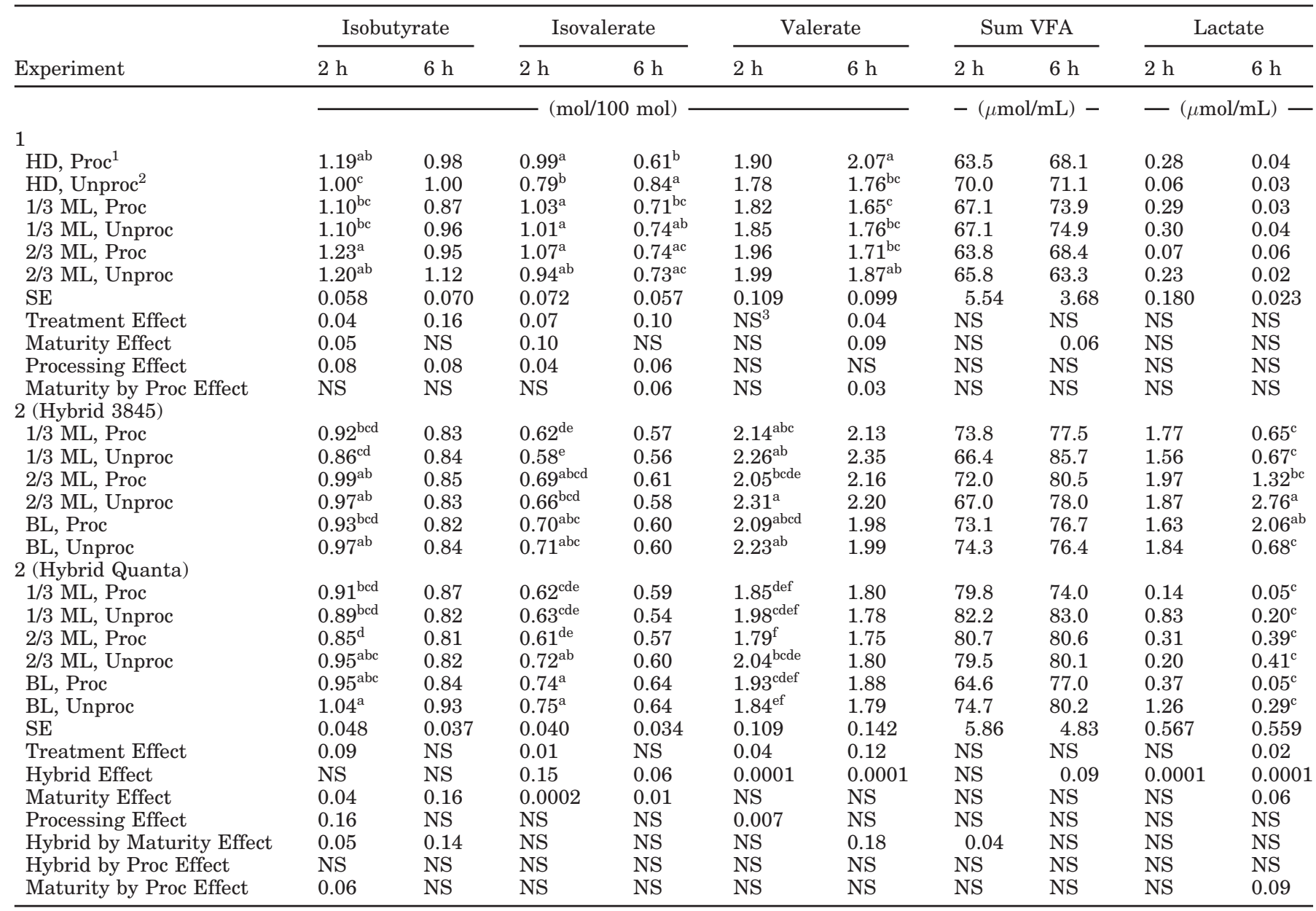

a,b,c,d,e, $f P \leq 0.09$.

${ }^{1}$ Proc - Corn silage harvested with kernel processing rolls set $1 \mathrm{~mm}$ apart.

${ }^{2}$ Unproc - Corn silage harvested with kernel processing rolls set $15.9 \mathrm{~mm}$ apart.

${ }^{3} \mathrm{NS}-P>0.10$.

age to concentrate ratio was similar across experiments, the overall increase in starch concentration for cows fed diets containing hybrid Quanta corn silage in experiment 2 (Johnson et al., 2002a) caused a shift in the types of VFA produced in the rumen.

Maturity of corn silage had an affect on ruminal acetate, propionate, and butyrate concentrations at 2 or 6 $\mathrm{h}$ after feeding (Table 8). Acetate concentrations in the rumen $2 \mathrm{~h}$ after feeding were significantly greater $(P<$ $0.01)$ at physiological maturity in experiment 2 (BL than one-third and two-thirds ML; Table 8). Six hours after feeding, acetate concentrations ( $\mathrm{mol} / 100 \mathrm{~mol})$ in the rumen tended to be greater at advanced maturities in experiments $1(P<0.06$; two thirds ML than hard dough and one-third $\mathrm{ML})$ and $2(P<0.07$; BL than onethird ML; Table 8). Propionate concentrations in the rumen $2(P<0.07)$ and $6 \mathrm{~h}(P<0.06)$ after feeding tended to be lower at physiological maturity (BL than two-thirds ML) in experiment 2 (Table 8). However, there was a hybrid by maturity interaction for propionate $2 \mathrm{~h}$ after feeding. The propionate concentration tended to be similar between maturities for hybrid 3845 , and was lower $(P<0.04)$ at BL compared to onethird ML and two-thirds ML for hybrid Quanta. In experiment 2 , the acetate to propionate ratio $2 \mathrm{~h}$ after feeding tended to be greater $(P<0.08)$ at BL compared to two-thirds ML (Table 8). The greater concentration of acetate and lower concentration of propionate in the rumen as maturity of corn silage in the diet advanced may be due to decreased digestibility of starch as maturity of corn silage advanced (Johnson et al., 2002b). Less starch tended to be digested by cows as maturity of corn silage advanced, therefore, less propionate was produced in the rumen. 
There was a hybrid by maturity interaction for butyrate concentration $2(P<0.09)$ and $6(P<0.003) \mathrm{h}$ after feeding. Butyrate concentrations were significantly lower at advanced maturities (BL and two-thirds ML than one-third ML) for hybrid 3845 in experiment 2 at $2(P<0.0001)$ and $6 \mathrm{~h}$ after feeding $(P<0.0002$; Table 8$)$. Butyrate concentrations tended to be similar between maturities $2 \mathrm{~h}$ after feeding for hybrid Quanta, and were significantly greater at one-third ML and physiological maturity (BL) compared to two-thirds ML for cows fed diets containing hybrid Quanta corn silage 6 $\mathrm{h}$ after feeding (Table 8).

Lactate concentrations $(\mu \mathrm{mol} / \mathrm{ml})$ were greater $2 \mathrm{~h}$ after feeding in experiment 2 than experiment 1 , where there were likely higher starch concentrations in the rumen (Tables 2, 3, and 9). In experiment 1 and for hybrid Quanta in experiment 2 there were negligible amounts of lactate in the rumen $6 \mathrm{~h}$ after feeding (Table 9). Van Soest (1994) indicated that typically, lactate levels are negligible by $6 \mathrm{~h}$ after feeding because they remain in the rumen only for 1 to $2 \mathrm{~h}$ before being fermented to acetate, propionate, or butyrate.

Overall, hybrid and maturity of corn silage had a greater influence on ruminal VFA and lactate concentrations than mechanical processing (Tables 8 and 9). The cows that were fed diets that contained corn silage with higher starch concentrations (hybrid Quanta; Johnson et al., 2002a) tended to have lower concentrations of acetate and higher concentrations of propionate in the rumen. Cows fed diets containing corn silage harvested at advanced stages of maturity (two-thirds ML and BL) tended to have greater concentrations of acetate and lower concentrations of propionate and butyrate in the rumen (Table 8). This trend was likely due to starch digestibility being lower for cows fed diets containing corn silage harvested at advanced maturities (Johnson et al., 2002b). However, mechanical processing of corn silage did not tend to alter the ruminal acetate, propionate, or butyrate concentrations in these experiments (Table 8). Bal et al. (2000a) also reported no differences in ruminal acetate and propionate concentrations.

Others reported a significant decline in ruminal acetate concentration after feeding when beef heifers (4, 8, and $16 \mathrm{~h}$ after feeding; Doggett, 1998) and lactating cows (Dhiman et al., 2000) were fed processed corn silage based diets. Propionate concentrations were greater for beef heifers $(P<0.10$; Doggett, 1998), steers $(P<0.05$; Rojas-Bourrillon et al., 1987), and lactating cows $(P<0.01$; Dhiman et al., 2000) fed processed corn silage based diets. The acetate to propionate ratio decreased when beef heifers $(P<0.009)$, steers $(P<0.05)$, and lactating cows were fed processed corn silage based diets (Doggett, 1998; Rojas-Bourrillon et al., 1987;
Miller et al., 1969). Butyrate concentrations $4 \mathrm{~h}$ after feeding $(P<0.02)$ were greater for beef heifers fed processed corn silage based diets (Doggett, 1998), and lower for lactating cows fed processed corn silage based diets (Bal et al., 2000a). The effect of feeding processed corn silage based rations on VFA concentrations in the rumen varied across the literature (Miller et al., 1969; Rojas-Bourrillon et al., 1987; Doggett, 1998; Bal et al., 2000a; Dhiman et al., 2000 ). However, there was a tendency among experiments for propionate concentrations to increase and acetate concentrations to decrease when cattle were fed processed corn silage diets. Therefore, the acetate to propionate ratio would be lower for cattle fed processed corn silage based diets.

\section{Milk Yield and Composition}

Milk yield and composition data should to be interpreted with caution because cows used in these metabolism studies varied in DIM (1 to 392 DIM) and the experimental design was a short-term feeding experiment (Table 10). Processing corn silage tended to reduce MUN concentrations in experiment 2 (10.4 vs. 11.2, respectively; $P<0.06$; Table 10). Others have reported a decrease $(P<0.07$; Johnson, 1996) or no difference (Bal et al., 2000a) in the concentration of MUN for cows fed processed compared to unprocessed corn silage based diets. The lower levels of MUN for cows fed processed corn silage suggest that there are more carbohydrates available for microbial $\mathrm{N}$ production because there is less ammonia being absorbed, converted to urea, and secreted in the milk.

Maturity of corn silage had an effect on milk fat and protein. In experiment 1, the milk protein concentration was lower $(P<0.02)$ for cows fed diets containing corn silage harvested at two-thirds ML, and total milk N concentration decreased $(P<0.04)$ as maturity advanced to two-thirds ML (Table 10). These results differ from published data that reported no difference in milk protein concentration for cows fed diets containing corn silage that varied from milk to physiological maturity (Johnson et al., 1999). In experiment 2, milk fat production was lower $(P<0.02)$ at physiological maturity (BL compared to one-third and two-thirds ML), and milk fat concentration was lower $(P<0.04)$ at BL than onethird ML (Table 10). These results differ from published data that reported no difference in milk fat production, and either no difference or an increase in milk fat concentration for cows consuming diets that ranged in corn silage maturity from milk to BL (Johnson et al., 1999).

The hybrid of corn silage fed to lactating cows in experiment 2 affected milk composition. The concentration of SNF (8.52 vs. 8.99\%) in milk was significantly lower $(P<0.0001)$ for cows fed diets containing hybrid 
Table 10. Body weight, milk production, and milk composition of cows in experiments 1 and 2 .

\begin{tabular}{|c|c|c|c|c|c|c|c|c|c|c|c|}
\hline Experiment & $\begin{array}{l}\text { Body } \\
\text { Weight }\end{array}$ & $\begin{array}{l}\text { Forage } \\
\text { NDF } \\
\text { Intake }\end{array}$ & Milk & FCM & Fat & Fat & Protein & Protein & SNF & $\begin{array}{l}\text { Total } \\
\mathrm{N}\end{array}$ & MUN \\
\hline & $(\mathrm{kg} / \mathrm{d})$ & $(\% \mathrm{BW})$ & $\longrightarrow(\mathrm{kg}$ & /d) & $(\%)$ & $(\mathrm{kg} / \mathrm{d})$ & $(\%)$ & $(\mathrm{kg} / \mathrm{d})$ & - & $\%)$ & $(\mathrm{mg} / \mathrm{dL})$ \\
\hline HD, Proc $^{1}$ & 650 & 0.76 & 26.0 & 27.6 & 3.81 & 1.01 & 3.19 & 0.80 & 8.69 & $0.618^{\mathrm{abc}}$ & 14.7 \\
\hline HD, Unproc ${ }^{2}$ & 652 & 0.73 & 25.3 & 26.8 & 3.84 & 0.98 & 3.28 & 0.81 & 8.75 & $0.622^{\mathrm{ab}}$ & 14.7 \\
\hline 1/3 ML, Proc & 647 & 0.68 & 23.8 & 25.2 & 3.76 & 0.92 & 3.35 & 0.77 & 8.76 & $0.641^{\mathrm{a}}$ & 15.0 \\
\hline 2/3 ML, Unproc & 649 & 0.71 & 27.5 & 29.9 & 4.05 & 1.11 & 3.10 & 0.84 & 8.64 & $0.592^{\text {cd }}$ & 15.8 \\
\hline $\mathrm{SE}$ & 23.4 & 0.03 & 4.05 & 4.39 & 0.325 & 0.175 & 0.196 & 0.094 & 0.240 & 0.014 & 0.89 \\
\hline Treatment Effect & $\mathrm{NS}^{3}$ & NS & NS & NS & NS & NS & NS & NS & NS & 0.04 & NS \\
\hline Maturity Effect & NS & 0.13 & NS & NS & NS & NS & 0.02 & NS & NS & 0.04 & NS \\
\hline Processing Effect & NS & NS & NS & NS & NS & NS & NS & NS & NS & NS & NS \\
\hline Maturity by Proc Effect & NS & NS & NS & NS & NS & NS & NS & NS & NS & NS & NS \\
\hline \multicolumn{12}{|l|}{2 (Hybrid 3845) } \\
\hline BL, Unproc & $640^{\text {cd }}$ & $0.74^{\mathrm{ab}}$ & $37.7^{\mathrm{a}}$ & $36.7^{\mathrm{b}}$ & $3.35^{\text {bcde }}$ & $1.26^{\mathrm{b}}$ & 2.97 & $1.12^{\mathrm{a}}$ & 8.60 & 0.639 & 11.6 \\
\hline \multicolumn{12}{|l|}{2 (Hybrid Quanta) } \\
\hline 1/3 ML, Proc & $650^{a b c}$ & $0.56^{\mathrm{ef}}$ & $31.9^{\mathrm{c}}$ & $29.8^{\mathrm{cd}}$ & $3.12^{\text {defg }}$ & $0.99^{\text {cd }}$ & 3.12 & $0.99^{\mathrm{bc}}$ & 8.71 & 0.562 & 9.8 \\
\hline 1/3 ML, Unproc & $655^{\mathrm{ab}}$ & $0.60^{\mathrm{e}}$ & $32.8^{\mathrm{bc}}$ & $31.1^{\mathrm{c}}$ & $3.17^{\text {cdef }}$ & $1.04^{\mathrm{c}}$ & 3.08 & $1.00^{\mathrm{bc}}$ & 8.77 & 0.553 & 11.3 \\
\hline 2/3 ML, Proc & $662^{\mathrm{a}}$ & $0.55^{\mathrm{f}}$ & $34.9^{\mathrm{b}}$ & $31.7^{\mathrm{c}}$ & $2.95^{\mathrm{fg}}$ & $1.03^{c}$ & 3.09 & $1.06^{\mathrm{ab}}$ & 8.76 & 0.572 & 10.8 \\
\hline 2/3 ML, Unproc & $654^{\mathrm{ab}}$ & $0.60^{\text {ef }}$ & $32.5^{\mathrm{bc}}$ & $30.0^{\text {cd }}$ & $3.06^{\text {efg }}$ & $0.99^{\text {cd }}$ & 3.08 & $0.99^{\mathrm{bc}}$ & 8.71 & 0.624 & 10.6 \\
\hline BL, Proc & $650^{\mathrm{abc}}$ & $0.58^{\text {ef }}$ & $32.8^{\mathrm{bc}}$ & $30.2^{\mathrm{cd}}$ & $3.03^{\text {efg }}$ & $0.98^{\mathrm{cd}}$ & 3.09 & $1.00^{\mathrm{bc}}$ & 8.75 & 0.505 & 10.8 \\
\hline BL, Unproc & $655^{\mathrm{ab}}$ & $0.60^{\mathrm{e}}$ & $30.7^{\mathrm{c}}$ & $27.3^{\mathrm{d}}$ & $2.88^{\mathrm{g}}$ & $0.87^{\mathrm{d}}$ & 3.09 & $0.95^{\mathrm{c}}$ & 8.77 & 0.615 & 11.9 \\
\hline SE & 5.9 & 0.024 & 1.25 & 1.37 & 0.141 & 0.061 & 0.050 & 0.040 & 0.069 & 0.046 & 0.846 \\
\hline Treatment Effect & 0.07 & 0.0001 & 0.0004 & 0.0001 & 0.002 & 0.0001 & NS & 0.02 & NS & NS & NS \\
\hline Hybrid Effect & 0.0001 & 0.0001 & NS & 0.0001 & 0.0001 & 0.0001 & 0.0001 & 0.0001 & 0.0001 & 0.0002 & 0.05 \\
\hline Maturity Effect & 0.07 & 0.05 & NS & 0.04 & 0.04 & 0.02 & NS & NS & NS & NS & NS \\
\hline Processing Effect & NS & 0.05 & NS & NS & NS & NS & NS & NS & NS & NS & 0.06 \\
\hline Hybrid by Maturity & NS & NS & NS & NS & NS & NS & NS & NS & NS & NS & NS \\
\hline
\end{tabular}

a,b,c,d $P \leq 0.09$.

${ }^{1}$ Proc - Corn silage was harvested with kernel processing rolls set $1 \mathrm{~mm}$ apart.

${ }^{2}$ Unproc - Corn silage was harvested with kernel processing rolls set $15.9 \mathrm{~mm}$ apart.

${ }^{3} \mathrm{NS}-P>0.10$.

Quanta corn silage compared to hybrid 3845 (Table 10). There was a significant depression in milk fat concentration $(3.07$ vs. $3.59 \% ; P<0.0001)$ and production $(1.07$ vs. $1.27 \mathrm{~kg} / \mathrm{d} ; P<0.0001)$ and milk protein concentration $(2.96$ vs. $3.20 \% ; P<0.0001)$ and production $(1.03$ vs. $1.12 \mathrm{~kg} / \mathrm{d} ; P<0.0001)$ for cows fed hybrid Quanta corn silage based diets compared to hybrid 3845 (Table 10). This was partially related to increased starch levels (35.9 vs. $25.4 \%$ ) for hybrid Quanta corn silage (Johnson et al., 2002a), and lower forage NDF levels in the diet as a percent of body weight $(0.62 \%$ vs. $0.68 \% ; P<0.0001$; Table 10). As starch intake increased, NDF intake declined for cows fed processed $\left(\mathrm{R}^{2}=0.24\right)$ and unprocessed $\left(R^{2}=0.94\right)$ corn silage diets (data not shown). The percentage of nonfiber carbohydrates in the TMR increased from approximately 27.6 to $39.0 \%$ between experiments 1 and 2 (Tables 2 and 3), and the forage
NDF as a percent of BW decreased from $0.71 \%$ to $0.65 \%$ between experiments 1 and 2 (Table 10).

Cows fed diets in experiment 1 almost met the recommendations of forage NDF concentration as a percentage of BW, and milk fat and milk protein concentrations were not depressed (Table 10). The forage NDF (\% of $\mathrm{BW}$ ) and total NDF (\% of BW) were on average 0.71 and $1.30 \%$, respectively, (experiment 2; Table 10 and Johnson et al., 2002b) and the recommendations suggested $0.75 \%$ forage NDF (\% of $\mathrm{BW}$ ) when the ration provided 1.3 to $1.4 \%$ of total NDF (Varga et al., 1998). However, when dietary levels of starch and nonfiber carbohydrates were high (experiment 2 ; Table 3 ), the forage NDF concentration as a percent of body weight $(0.65 \%)$ was below the recommended level of 0.85 percentage units. In experiment 2 for hybrids 3845 and Quanta, forage NDF as percent of body weight was 0.71 

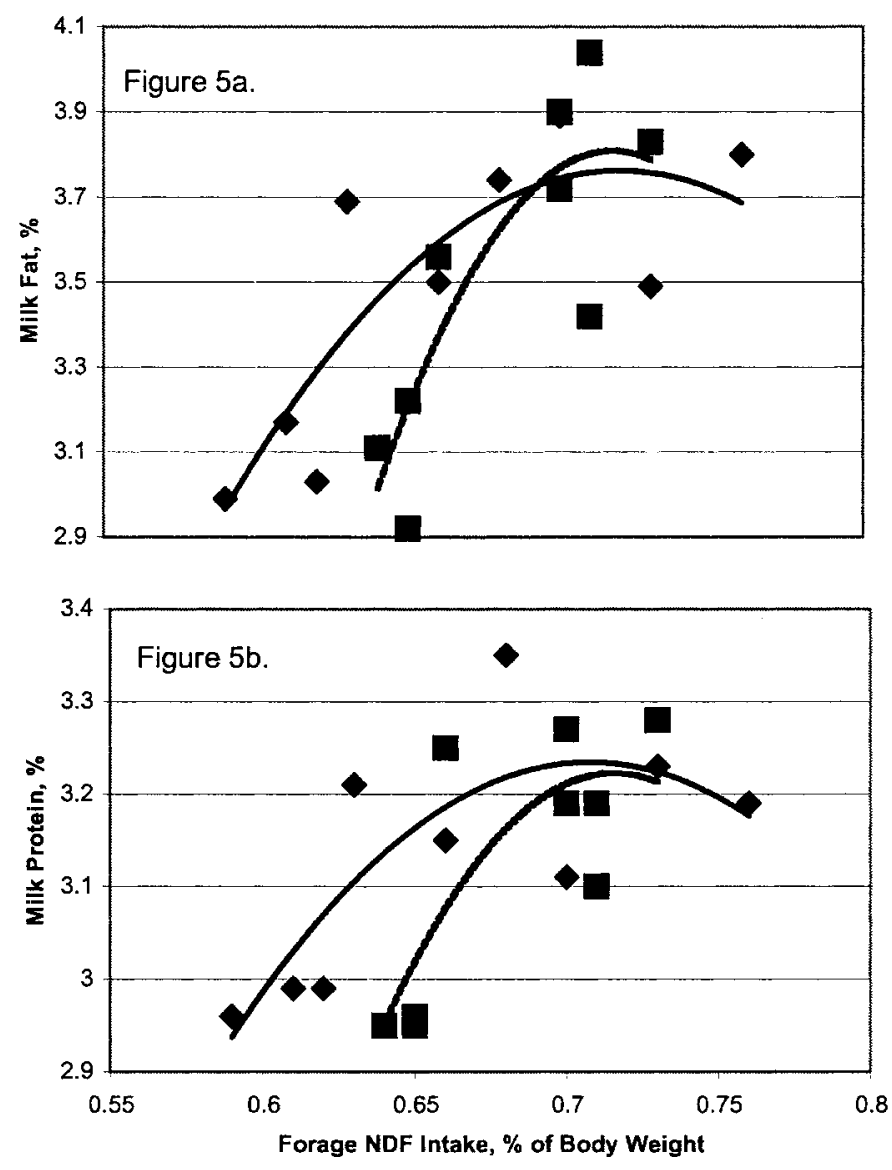

Figure 5. Effect of forage NDF intake (\% of body weight) on milk fat concentration (Figure 5a) and milk protein concentration (Figure $5 \mathrm{~b}$ ) for cows fed mechanically processed ( ) or unprocessed ( $\square$ ) corn silage based diets. Each data point represents a mean for each treatment in experiments 1 and 2. Figure 6a: Processed (-), $\mathrm{Y}=-47.311 \mathrm{x}^{2}$ $+68.113 \mathrm{x}-20.753, \mathrm{R}^{2}=0.6937, P<0.03$. Unprocessed (---), $\mathrm{Y}=$ $-132.79 \mathrm{x}^{2}+190.53 \mathrm{x}-64.533, \mathrm{R}^{2}=0.703, P<0.03$. Figure $6 \mathrm{~b}$ : Proc essed (一), $\mathrm{Y}=-21.422 \mathrm{x}^{2}+30.322 \mathrm{x}-7.4954, \mathrm{R}^{2}=0.6099, P<0.06$. Unprocessed (---), $\mathrm{Y}=-47.168 \mathrm{x}^{2}+67.518 \mathrm{x}-20.94, \mathrm{R}^{2}=0.6051, P$ $<0.06$.

and $0.58 \%$ (Table 10), respectively, and NDF as percent of body weight was 1.26 and $1.12 \%$, respectively (Johnson et al., 2002b). The fact that forage NDF concentrations (\% of $\mathrm{BW}$ ) were lower than recommended, and that three of the cows were in early lactation (averaged $26 \mathrm{DIM}$ at the beginning of the experiment), contributed to the depression in milk fat and protein concentrations and production for cows fed diets containing hybrid Quanta in experiment 2.

Forage NDF intake as a percent of body weight explained $69(P<0.03)$ and $70 \%(P<0.03)$ of the variation in milk fat concentration for cows fed processed and unprocessed corn silage diets, respectively (Figure 5a). Also, forage NDF intake as a percent of body weight explained $61 \%(P<0.06)$ of the variation in milk protein concentration for cows fed processed and unprocessed corn silage diets (Figure 5b). Milk fat and milk protein concentrations were at normal levels when forage NDF intake, as a percent of BW, was greater than $0.7 \%$ (Figures $5 \mathrm{a}$ and $5 \mathrm{~b}$ ). However, there was a rapid decline in the concentration of fat and protein in milk when forage $\mathrm{NDF}$ intake as a percent of body weight dipped below $0.7 \%$ (Figures $5 \mathrm{a}$ and $5 \mathrm{~b}$ ).

\section{CONCLUSIONS}

Mechanical processing affected DM, OM, and N digestion, ruminal fermentation, and MUN concentration in this study. Total tract digestibilities of DM, OM, and $\mathrm{N}$ were greater for cows fed unprocessed corn silage diets in experiment 1 . Rate of passage may have been the limiting factor for digestion in experiment 1 . The TLC $(6.4 \mathrm{~mm})$ of corn silage was short in experiment 1 , and the processed corn silage had a reduced mean particle size compared to the unprocessed corn silage. Therefore, diets containing processed corn silage may have passed from the digestive tract faster than the unprocessed corn silage diet, and DM, OM, and $\mathrm{N}$ digestion were limited due to the increased rate of passage. In experiment 2 , there was a trend for greater digestion of DM and OM in the total tract for cows fed diets containing processed corn silage compared to unprocessed corn silage. Ruminal $\mathrm{pH}$ tended to be lower for cows fed diets containing processed corn silage in experiment 2, and cows fed processed corn silage based diets tended to have a reduced MUN concentration in the milk compared to unprocessed corn silage in experiment 2. This is an indication that there were more carbohydrates available for microbial $\mathrm{N}$ production because there was less ammonia being absorbed, converted to urea, and secreted in the milk.

Maturity of corn silage affected $\mathrm{OM}$ digestion, $\mathrm{N}$ metabolism, ruminal fermentation, and milk composition. Organic matter truly digested in the rumen and microbial $\mathrm{N}$ concentration were significantly lower for cows fed diets containing corn silage harvested at one-third ML compared to hard dough and two-thirds ML in experiment 1 . The lower concentration of microbial $\mathrm{N}$ in the rumen led to increased flow of feed N (NANMN) from the duodenum at one-third ML (experiment 1).

Ruminal acetate concentrations were greater and ruminal propionate concentrations were lower 2 and $6 \mathrm{~h}$ after feeding for cows fed diets containing corn silage harvested at physiological maturity (BL) in experiment 2 . Therefore, the acetate to propionate ratio was greater at $2 \mathrm{~h}$ after feeding for cows fed diets containing corn silage harvested at physiological maturity. This was due to decreased digestion of starch at advanced matu- 
rities. Milk fat concentration and production were lower at physiological maturity (BL) in experiment 2 .

Hybrid of corn silage affected nitrogen metabolism, ruminal fermentation, and milk composition. Microbial $\mathrm{N}$ flow was lower and feed N (NANMN) flow to the duodenum was greater for cows fed diets containing hybrid Quanta corn silage compared to hybrid 3845 corn silage. The lower MNF was due to lower microbial $\mathrm{N}$ concentration and lower NAN flow to the duodenum. Microbial N efficiency was lower for cows fed diets containing hybrid Quanta corn silage compared to hybrid 3845 corn silage based diets. This was due to decreased microbial $\mathrm{N}$ flow and decreased true digestion of $\mathrm{OM}$ in the rumen for cows fed hybrid Quanta corn silage based diets.

Ruminal $\mathrm{pH}$ tended to decline at a faster rate for cows fed diets containing hybrid Quanta ( $2 \mathrm{~h}$ after feeding) compared to hybrid 3845 corn silage ( $5 \mathrm{~h}$ after feeding; experiment 2). Ruminal acetate concentrations decreased and ruminal propionate concentrations increased 2 and $6 \mathrm{~h}$ after feeding for cows fed diets containing hybrid Quanta corn silage compared to hybrid 3845 corn silage. This was related to the increased concentration of starch in the corn silage, increased starch NDF intake, and increased rate of starch digestion in the rumen for cows fed diets containing hybrid Quanta compared to hybrid 3845 corn silage.

Milk fat and protein concentrations and production were lower for cows fed diets containing hybrid Quanta corn silage compared to hybrid 3845 corn silage. The reduction was due to increased starch concentration in the corn silage, increased starch intake, and decreased forage NDF as a percent of BW in the diet. Milk fat and protein concentrations were strongly related to forage intake as a percent of body weight. Milk fat and protein concentrations were at normal levels until forage NDF intake, as a percent of $\mathrm{BW}$, went below approximately $0.70 \%$. When forage NDF intake, as a percent of BW, dropped below $0.70 \%$ there was a rapid decline in milk fat and protein concentrations.

Particle size of corn silage, starch intake, starch digestion, and forage NDF intake as a percent of BW are some of the main factors that influenced the results observed in this paper. Mechanical processing tended to reduce total tract digestion of $\mathrm{DM}$ and $\mathrm{OM}$ when the TLC of corn silage was short $(6.4 \mathrm{~mm})$, and tended to improve total tract digestion of $\mathrm{DM}$ and $\mathrm{OM}$ when the TLC was longer $(12.7 \mathrm{~mm})$. Therefore, the authors would recommend that the particle size of the corn silage should be at least $12.7 \mathrm{~mm}$ when processing corn silage. Ruminal fermentation ( $\mathrm{pH}$, acetate, and propionate) parameters were affected when the amount and digestibility of starch in the diet changed. Milk fat and protein concentration and production were influ- enced by forage NDF intake (\% of BW). Based on these results it is important to know the concentration and digestibility of starch in corn silage and the level of forage NDF (\% of BW) in the diet to maintain rumen $\mathrm{pH}$ and VFA profiles at a level that promotes a healthy rumen microbial population and to avoid a depression in milk fat and protein.

\section{REFERENCES}

Aldrich, J. M., L. D. Muller, G. A. Varga, and L. C. Griel, Jr. 1993. Nonstructural carbohydrate and protein effects on rumen fermentation, nutrient flow, and performance of dairy cows. J. Dairy Sci. 76:1091-1105.

Association of Official Analytical Chemists. 1990. Official Methods of Analysis. 15th ed. AOAC, Arlington, VA.

Bal, M. A., J. G. Coors, and R. D. Shaver. 1997. Impact of the maturity of corn for use as silage in the diets of dairy cows on intake, digestion, and milk production. J. Dairy Sci. 80:2497-2503.

Bal, M. A., R. D. Shaver, A. G. Jirovec, K. J. Shinners, and J. G. Coors. 2000a. Crop processing and chop length of corn silage: Effects on intake, digestion, and milk production in dairy cows. J. Dairy Sci. 83:1264-1273.

Bal, M. A., R. D. Shaver, K. J. Shinners, J. G. Coors, J. G. Lauer, R. J. Straub, and R. G. Koegel. 2000b. Stage of maturity, processing, and hybrid effects on ruminal in situ disappearance of wholeplant corn silage. Anim. Feed Sci. Technol. 86:83-94.

Clark, J. H., T. H. Klusmeyer, and M. R. Cameron. 1992. Microbial protein synthesis and flows of nitrogen fractions to the duodenum of dairy cows. J. Dairy Sci. 75:2304-2323.

Deetz, D. A., J. H. Harrison, F. R. Valdez, and D. W. Evans. 1989. Impact of noncorrosive forage stabilizers on digestibility of alfalfa hay and lactation performance of dairy cows. J. Dairy Sci. 72:2062-2073.

Dhiman, T. R., M. A. Bal, Z. Wu, V. R. Moreira, R. D. Shaver, L. D. Satter, K. J. Shinners, and R. P. Walgenbach. 2000. Influence of mechanical processing on utilization of corn silage by lactating dairy cows. J. Dairy Sci. 83:2521-2528.

Doggett, C. G. 1998. Evaluation of the effect of corn hybrid and processing on digestion of whole plant silage, grain and stover. MS Thesis, Univ. Idaho, Moscow, Idaho.

Erwin, E. S., G. J. Marco, and E. M. Emery. 1961. Volatile fatty acid analysis of blood and rumen fluid by gas chromatography. J. Dairy Sci. 44:1768-1771.

Fassel, V. A. 1978. Quantitative elemental analyses by plasma emission spectrophotometry. Science 202:183-191.

Goering, H. K., and P. J. Van Soest, 1970. Forage Fiber Analyses (Apparatus, Reagents, Procedures, and Some Applications). Agric. Handbook No. 379. ARS-USDA, Washington, DC.

Goering, H. K., R. W. Hemken, N. A. Clark, and J. H. Vandersall. 1969. Intake and digestibility of corn silages of different maturities, varieties, and plant populations. J. Anim. Sci. 29:512-518.

Harrison, J. H., L. Johnson, C. Hunt, C. D. Doggett, C. A. Rotz, K. Shinners, and D. Sapienza. 1998. Mechanical processing of corn silage: looking back two years. Western Washington Horticultural Assoc. Annu. Conv., Seattle, WA.

Harrison, J. H., L. Johnson, R. Riley, S. Xu, K. Loney, C. W. Hunt, and D. Sapienza. 1996. Effect of harvest maturity of whole plant corn silage on milk production and component yield and passage of corn grain and starch into feces. J. Dairy Sci. 79(Suppl. 1):149.

Holm, I. B., A. Drews, and N. G. Asp, Lund. 1986. A rapid method for the analysis of starch. Starch Staerke 38:7:224-226.

Jirovec, A. G., K. J. Shinners, R. D. Shaver, M. Bal, R. J. Straub, and R. G. Koegel. 1998. Physical properties of wilted alfalfa and whole-plant corn silages processed with crop processing rolls. ASAE paper no. 981119. American Society of Agricultural Engineers, St. Joseph, MI.

Johnson, L. M., J. H. Harrison, D. Davidson, J. Robutti, M. Swift, B. Mahanna, and K. Shinners. 2002a. Corn Silage Management 
I: Effects of hybrid, maturity, and mechanical processing on chemical and physical characteristics. J. Dairy Sci. 85: In Press.

Johnson, L. M., J. H. Harrison, D. Davidson, M. Swift, B. Mahanna, K. Shinners. 2002b. Corn Silage Management II: Effects of hybrid, maturity, and mechanical processing on digestion and energy content. J. Dairy Sci. In Press.

Johnson, L., J. H. Harrison, C. Hunt, K. Shinners, C. G. Doggett, and D. Sapienza. 1999. Nutritive value of corn silage as affected by maturity and mechanical processing: a contemporary review. J. Dairy Sci. 82:2813-2825.

Johnson, L. 1996. Characterization of the relationship between duodenal flow of ruminal microbial nitrogen production and purine metabolites in urine and milk. MS Thesis, Washington State Univ., Pullman.

Johnson, R. R., and K. E. McClure. 1968. Corn plant maturity. IV. Effects on digestibility of corn silage in sheep. J. Anim. Sci. 27:535-540.

Mertens, D. R. 1993. Pages 554-567 in Forage Cell Wall Structure and Digestibility. American Society of Agronomy, Inc., Crop Science Society of America, Inc., Soil Science Society of America, Inc., Madison, WI.

Miller, C. N., C. E. Polan, R. A. Sandy, and J. T. Huber. 1969. Effect of altering physical form of corn silage on utilization by dairy cattle. J. Dairy Sci. 52:1955-1960.

National Research Council. 1989. Nutrient Requirements of Dairy Cattle. 6th rev. ed. Natl. Acad. Sci., Washington, DC.

National Research Council. 1985. Ruminant Nitrogen Usage. Natl. Acad. Sci., Washington, DC.

Rohr, V. K, P. Lebzien, H. Schafft, and H. Honig. 1986. The effect of reducing the particle size of maize silage on metabolism in the rumen of cows. J. Anim. Phys. Anim. Nutr. 55:121-128.
Rojas-Bourrillon, A., J. R. Russell, A. Trenkle, and A. D. McGilliard, 1987. Effects of rolling on the composition and utilization by growing steers of whole-plant corn silage. J. Anim. Sci. 64:303311.

SAS User's Guide: Statistics. Version 6.03 Edition. 1988. SAS Inst., Inc., Cary, NC.

Satter, L. D., and L. L. Slyter. 1974. Effect of ammonia concentration on rumen microbial protein production in vitro. Br. J. Nutr. 32:199-208.

St. Pierre, N. R., R. Bouchard, G. St. Laurent, G. L. Roy, and C. Vinet. 1987. Performance of lactating dairy cows fed silage from corn of varying maturities. J. Dairy Sci. 70:108-115.

Van Soest, P. J. 1994. Nutritional ecology of the ruminant. 2nd ed. Cornell University Press, Ithaca, NY.

Van Soest, P. J., J. B. Roberston, and B. A. Lewis. 1991. Methods for dietary fiber, neutral detergent fiber, and non-starch polysaccharides in relation to animal nutrition. J. Dairy Sci. 74:35833597.

Varga, G. A., H. M. Dann, and V. A. Ishler. 1998. The use of fiber concentrations for ration formulation. J. Dairy Sci. 81:3063-3074

Weiss, W. P., and D. J. Wyatt. 2000. Effect of oil content and kernel processing of corn silage on digestibility and milk production by dairy cows. J. Dairy Sci. 83:351-358

Williams, C. H., D. J. David, and O. Iismaa. 1962. The determination of chromic oxide in faecal samples by atomic absorption spectrophotometry. J. Agri. Sci. 59:381-385.

Young, M. A., T. J. Wistuba, B. E. Brent, L. H. Harbers, and K. K. Bolsen. 1998. The effect of processing corn silage on feedlot performance and nutrient digestibility in growing cattle. J. Anim. Sci. 76(Suppl. 1):199.

Zinn, R. A., and F. N. Owens. 1986. A rapid procedure for purine measurement and its use for estimating net ruminal protein synthesis. Can. J. Anim. Sci. 66:157-166. 